OPEN ACCESS

Edited by:

Andras Bilkei-Gorzo,

University of Bonn, Germany

Reviewed by: Maria Morena,

University of Calgary, Canada

Gianluca Serafini,

University of Genoa, Italy

*Correspondence:

Alline C. Campos

allinecampos@usp.br

${ }^{\dagger}$ These authors have contributed equally to this work.

Received: 28 September 2017 Accepted: 27 November 2017 Published: 19 December 2017

Citation:

Scarante FF, Vila-Verde C, Detoni VL,

Ferreira-Junior NC, Guimãraes FS and Campos AC (2017) Cannabinoid

Modulation of the Stressed

Hippocampus.

Front. Mol. Neurosci. 10:411.

doi: 10.3389/fnmol.2017.00411

\section{Cannabinoid Modulation of the Stressed Hippocampus}

\author{
Franciele F. Scarante ${ }^{\dagger}$, Carla Vila-Verde ${ }^{\dagger}$, Vinícius L. Detoni, Nilson C. Ferreira-Junior, \\ Francisco S. Guimarães and Alline C. Campos*
}

Department of Pharmacology, School of Medicine of Ribeirão Preto, Centre for Interdisciplinary Research on Applied Neurosciences (NAPNA), Cannabinoid Research Institute, University of São Paulo, São Paulo, Brazil

Exposure to stressful situations is one of the risk factors for the precipitation of several psychiatric disorders, including Major Depressive Disorder, Posttraumatic Stress Disorder and Schizophrenia. The hippocampal formation is a forebrain structure highly associated with emotional, learning and memory processes; being particularly vulnerable to stress. Exposure to stressful stimuli leads to neuroplastic changes and imbalance between inhibitory/excitatory networks. These changes have been associated with an impaired hippocampal function. Endocannabinoids (eCB) are one of the main systems controlling both excitatory and inhibitory neurotransmission, as well as neuroplasticity within the hippocampus. Cannabinoids receptors are highly expressed in the hippocampus, and several lines of evidence suggest that facilitation of cannabinoid signaling within this brain region prevents stress-induced behavioral changes. Also, chronic stress modulates hippocampal $\mathrm{CB}_{1}$ receptors expression and endocannabinoid levels. Moreover, cannabinoids participate in mechanisms related to synaptic plasticity and adult neurogenesis. Here, we discussed the main findings supporting the involvement of hippocampal cannabinoid neurotransmission in stressinduced behavioral and neuroplastic changes.

\footnotetext{
Keywords: hippocampus, stress, HPA axis, endocannabinoid system, $\mathrm{CB}_{1}, \mathrm{CB}_{2}$, neuroplasticity
}

\section{CANNABINOID SIGNALING}

Humankind has been using Cannabis sativa for therapeutic and recreational purposes since ancient times (Mechoulam and Parker, 2013). In the early 60s, Raphael Mechoulam's group isolated and described the chemical structures of more than 60 compounds, named cannabinoids, present in this plant (Gaoni and Mechoulam, 1964). Following this achievement, it was demonstrated in the 80s that the effects of cannabimimetic drugs were mediated by their interaction with specific sites, resulting in the activation of a $G$ protein signaling and the inhibition of adenylate cyclase activity (Howlett and Fleming, 1984; Howlett, 1985). Devane et al. (1988) identified a specific binding site for $\Delta 9$-tetrahydrocannabinol (THC; the main psychotomimetic compound of the plant) in the rat brain. Later, this binding site was cloned and named Cannabinoid type 1 receptor or $\mathrm{CB}_{1}$ (Matsuda et al., 1990). A few years later, a second cannabinoid receptor, $\mathrm{CB}_{2}$, was also described (Munro et al., 1993). Together, these findings provided the basis for the elucidation of a complete new endogenous system: the endocannabinoid system (eCBS). In parallel with the discovery of the two-cannabinoid receptors, endogenous ligands, named endocannabinoids (eCB), were also described (Devane et al., 1992; Mechoulam et al., 1995). So far, the most studied $\mathrm{eCB}$ are the ones derived from membrane phospholipids, particularly arachidonoyl ethanolamide or anandamide (AEA), and 2-arachidonoyl glycerol (2-AG; Maccarrone et al., 2014). 

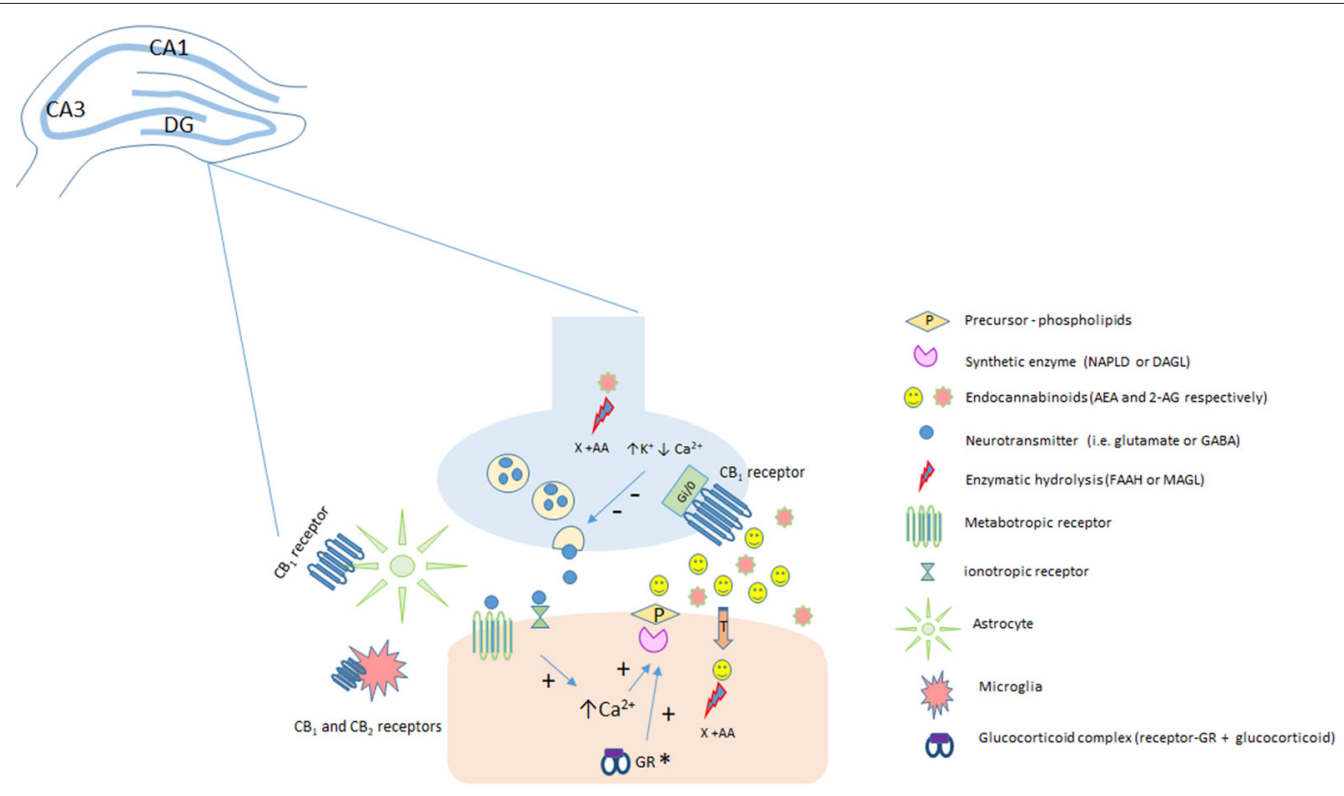

FIGURE 1 | Classical representation of endocannabinoid modulation in the hippocampus. Anandamide (AEA) and 2-AG are produced "on demand" in a calcium $\left(\mathrm{Ca}^{2+}\right)$-dependent manner (via the previous activation of a metabotropic or ionotropic receptor in the post-synaptic terminal). After the synthesis of endocannabinoids (eCBs) by specialized enzymes, they can act as retrograde messengers by activating $\mathrm{CB}_{1}$ receptors located at pre-synaptic terminals. In neurons, $\mathrm{CB}_{1}$ is a Gi/o-coupled receptor, and its activation reduces Ca2+ currents and increases K+ currents, leading to the inhibition of neurotransmitter release. Fatty-acid amide hydrolase (FAAH) and monoacylglycerol lipase (MAGL) enzymes hydrolyze AEA (postsynaptically) and 2-AG (presynaptically), respectively, limiting eCB action. The $\mathrm{CB}_{1}$ receptor is also expressed in astrocytes and microglia and the $\mathrm{CB}_{2}$ receptor is expressed in activated microglia and putatively expressed in neurons (still under debate). *It has been speculated, that in the hippocampus, stress-induced activation of the HPA could lead, depending on genomic actions of glucocorticoids acting at glucocorticoid receptors, to an increase in 2-AG levels. 2-AG, 2-arachidonoylglycerol; $\mathrm{AEA}$, anandamide; $\mathrm{CB}_{1}$, type 1 cannabinoid receptor; $\mathrm{CB}_{2}$, type 2 cannabinoid receptor; DAGL, diacylglycerol lipase; FAAH, fatty acid amide hydrolase; GR, glucocorticoid receptors; MAGL, monoacylglycerol lipase; NAPE-PLD, $\mathrm{N}$-acyl phosphatidylethanolamine-specific phospholipase D.

$\mathrm{eCB}$ are recognized now as neuromodulators synthetized "on demand" after cell depolarization or receptor stimulation (e.g., NMDA, mGlu5) by specific enzymes (AEA: N-acylphosphatidylethanolamine phospholipase, D-NAPE-PLD; 2-AG: $\alpha$ and $\beta$ isoforms of diacylglycerol lipase, DAGL; Saito et al., 2010). Fatty-acid amide hydrolase (FAAH) and monoacylglycerol lipase (MAGL) are the main enzymes that metabolize AEA and 2-AG, respectively, ending eCB actions (Cravatt et al., 1996; Dinh et al., 2004; Figure 1).

$\mathrm{CB}_{1}$ receptors are widely distributed in the Central Nervous System (CNS) and primarily expressed in pre-synaptic terminals where eCBs can act as retrograde messengers (Wilson and Nicoll, 2001; Maccarrone et al., 2014). In the CNS, this $\mathrm{G}_{\mathrm{i} / 0}$-coupled protein receptor is densely expressed in neurons. Once activated, it leads to a decreased probability of neurotransmitter release (GABA, glutamate, etc.), via inhibition of presynaptic $\mathrm{Ca}^{2+}$ channels and activation of $\mathrm{K}^{+}$channels (Mackie et al., 1995; Kreitzer et al., 2001).

eCBs are involved in short- and long-term plasticity in several brain structures such as the amygdala (Azad et al., 2004), nucleus accumbens (Robbe et al., 2002), striatum (Gerdeman et al., 2002) and hippocampus (Ohno-Shosaku et al., 2007; Zhu and Lovinger, 2007; Izumi and Zorumski, 2012). Despite the canonical signaling pathways via $\mathrm{G}_{\mathrm{i} / 0}$-coupled protein receptors, studies indicate the existence of $\mathrm{CB}_{1}$ receptors coupled to $\mathrm{G}_{\mathrm{q}}$ proteins in hippocampal neurons (Lauckner et al., 2005) and astrocytes (Navarrete and Araque, 2010; Lutz et al., 2016). eCBs released by neurons can bind to $\mathrm{Gq}$-coupled $\mathrm{CB}_{1}$ receptors present in astrocytes, thus promoting glutamate release from these glial cells (Navarrete and Araque, 2010; Lutz et al., 2016).

Although still under debate, some studies have also suggested the neuronal expression of $\mathrm{CB}_{2}$ receptors (Brusco et al., 2008; $\mathrm{Li}$ and Kim, 2016; Stempel et al., 2016). However, others report that the messenger RNA expression of this cannabinoid receptor is negligible (400-2000-fold times lower than $\mathrm{CB}_{1}$ receptor mRNA) in the CNS (Marco et al., 2014). $\mathrm{CB}_{2}$ is expressed in primed microglial cells (Núñez et al., 2004), influencing the microglia phenotypes by polarizing these cells to M2-type (alternative/antiinflammatory; Mecha et al., 2015; Li and Kim, 2017) through the cAMP/PKA pathway (Tao et al., 2016).

The precise endogenous function of eCBs is still under investigation, but several lines of evidence suggest that impairment of eCB neuromodulation is associated with neuropsychiatric disorders such as major depressive disorders (MD), schizophrenia and anxiety disorders (Hillard et al., 2012; Pacher and Kunos, 2013). Supporting this proposal, for example, rimonabant, a $\mathrm{CB}_{1}$ receptor antagonist/inverse agonist, which years ago was marketed for the treatment of tobacco abuse, obesity and associated metabolic disorders, was withdrawn from the market due to its psychiatric side effects 
(Moreira and Crippa, 2009). Major depressive patients had a significantly higher frequency of a mutant allele of the CNR1 (rs1049353; Monteleone et al., 2010). Accordingly, $\mathrm{CB}_{1}$ receptor had a higher expression in the prefrontal cortex of patients with major depressive disorder (Choi et al., 2012). Recently, it was also observed a significant increase in $\mathrm{CB}_{1}$ expression, and a reduction in mechanisms of DNA methylation at the promoter of CNR1, the gene coding for the $\mathrm{CB}_{1}$ receptor in schizophrenia patients (D'Addario et al., 2017). The CNR1 gene is located at the chromosome 6q14-15, a locus possible related to susceptibility for bipolar affective disorder (Rice et al., 1997; Abou Jamra et al., 2010). Moreover, a direct association between CNR1, CNR2 and FAAH polymorphisms and bipolar disorder susceptibility has also been described (Monteleone et al., 2010; Minocci et al., 2011).

Exposure to stressful situations changes eCB signaling and increases the susceptibility to psychiatric disorders (Hill et al., 2010; Hillard, 2014). Cannabinoid receptors, eCBs (AEA and 2-AG), and the enzymes responsible for their synthesis and deactivation are widely expressed in the hippocampus (Tsou et al., 1998; Katona et al., 1999). Impairments in hippocampusdependent functions (e.g., cognitive deficits, affect lability and dysregulated pattern separation) are a common feature of psychiatric patients (David et al., 2010; Christian et al., 2014; Kang et al., 2016). Therefore, in the next topic of the present manuscript, we revised studies that have explored the role of hippocampal eCB-signaling during stressful situations.

\section{STRESS MODULATION OF ECB SIGNALING IN THE HIPPOCAMPUS}

Several studies strongly suggest that eCBs reduce hypothalamic-pituitary-adrenal (HPA) axis activation and facilitate appropriate stress recovery (Patel et al., 2004, 2009; Balsevich et al., 2017). However, the impact of stressful experiences in the eCBs appears to be quite complex, depending on the intensity, duration, and nature/type of the stressor, and the brain region investigated (Patel et al., 2004; Rubino et al., 2008; Campos et al., 2010; Hill et al., 2010; Figure 2).

The hippocampus is a forebrain structure that presents a very high expression of $\mathrm{CB}_{1}$ receptors (Tsou et al., 1998), mainly in cholecystokinin (CCK)-positive GABAergic interneurons (Katona et al., 1999). In addition, lower expression of $\mathrm{CB}_{1}$ receptors can be also found in glutamatergic, serotonergic, and cholinergic neurons. Also present in glial cells, $\mathrm{CB}_{1}$ receptors participate in the neuron-astrocyte communication in the hippocampus (Navarrete and Araque, 2008).

The hippocampal formation has been recognized as an important site for the deleterious effects of uncontrollable stress in brain function (McEwen, 1999). The hippocampus negatively modulates the HPA axis, one of the main players in stress regulation in mammals. HPA activation leads to the release of glucocorticoids, mediators of the countless effects of stress on the hippocampus function (Kim et al., 1996).

Pharmacological and genetic studies support the role of $\mathrm{eCBs}$ as regulators of emotional processing in the hippocampus

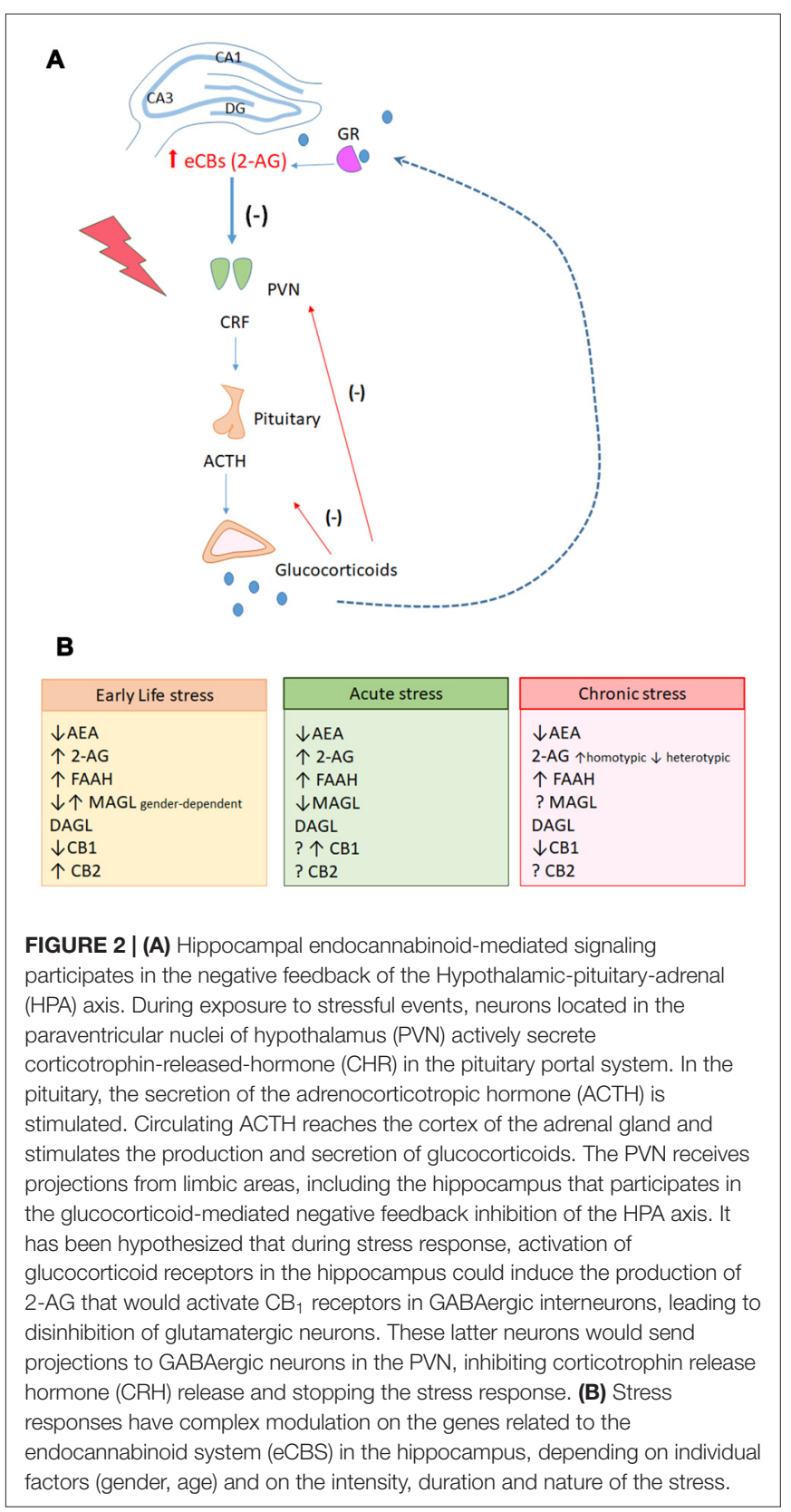

(Akirav, 2011; Jenniches et al., 2016). However, conflicting results have been observed, probably because of the diverse components of the eCB system, the wide influence of $\mathrm{CB}_{1}$ receptor signaling in different neuronal circuits, and external factors, such as stress protocols, animal strain, treatment dosage, and even the choice of the pharmacological/genetic tool (Hill and Gorzalka, 2005; Roohbakhsh et al., 2007; Dubreucq et al., 2012; Reich et al., 2013; Korem and Akirav, 2014; Zhong et al., 2014; Zhang et al., 2015).

\section{Nature, Duration and Controllability of Stress and eCBS}

AEA and 2-AG could differently modulate emotional-related responses. In brain areas related to neuropsychiatric disorders, 
exposure to acute stress leads to a rapid decrease of AEA while inducing a delayed increased in 2-AG levels (Hill and Tasker, 2012). In the hippocampus, exposure to restraint (Wang et al., 2012) or social defeat stress (Dubreucq et al., 2012) reduces the levels of AEA whereas increases 2-AG. Interestingly, early life stressors (maternal separation and prenatal restraint stress) also decreased AEA levels in the hippocampus but increased 2-AG in male rodents (Llorente et al., 2008; Marco et al., 2013). Stress-induced changes in eCBs levels could be partially mediated by increased FAAH activity (Navarria et al., 2014) and reduction of 2-AG hydrolysis by MAGL (Suárez et al., 2010). The stress-effect on MAGL, however, has generated conflicting results and appears to be gender-dependent (Marco et al., 2014). On the other hand, 2-AG content seems to be influenced by corticosterone levels in acute stress protocols (Hill et al., 2011b; Atsak et al., 2012; Wang et al., 2012).

The severity and the nature of the stress protocol could differently modulate eCBs. In foot-shock based protocols, changes in AEA content seem to depend on the intensity and duration of the foot-shock protocol, as well as the time-window of the analysis. For example, Morena et al. (2014) described increased AEA levels $10 \mathrm{~min}$ after the stress in limbic areas, including the hippocampus, of rodents submitted to $0.45-\mathrm{mA} / 1 \mathrm{~s}$ foot-shock protocol. In contrast, another study, using six foot-shocks of $0.7 \mathrm{~mA}$, found a reduction in AEA levels in the hippocampus $24 \mathrm{~h}$ after the end of the stress protocol (Bluett et al., 2014). In these two studies, however, no changes in 2-AG levels were observed in the hippocampus (Bluett et al., 2014; Morena et al., 2014).

Even if there are contradictory results (Bortolato et al., 2007; Lomazzo et al., 2015), the effect of homotypic chronic stress on eCB levels are similar to those observed after acute stress. They include an early decreased of AEA levels (due to increased FAAH activity) and a delayed increase in 2-AG levels (due to reduced MAGL activity; Hill et al., 2010; Dubreucq et al., 2012). Repeated restraint stress elevated 2-AG levels exclusively in the amygdala, while social defeat stress increased 2-AG content only in the hippocampus (Hill et al., 2010; Dubreucq et al., 2012). Some studies in rodents submitted to heterotypic protocols, such as the chronic unpredictable stress (CUS), report reduced AEA and 2-AG levels (Hill et al., 2008b; Zhong et al., 2014), and increased FAAH expression in the hippocampus (Reich et al., 2009), while others show no changes in eCBs levels after CUS protocols (Bortolato et al., 2007).

Stress can also influence $\mathrm{CB}_{1}$ function. Korem and Akirav (2014) demonstrated that a single footshock episode increased $\mathrm{CB}_{1}$ receptors expression in the $\mathrm{CA}_{1}$ region of the hippocampus (Korem and Akirav, 2014). On the other hand, chronic stress is associated with a down-regulation of $\mathrm{CB}_{1}$ receptor signaling in this brain structure (Hill and Gorzalka, 2005; Hill et al., 2008b; Reich et al., 2009; Hu et al., 2011; Lee and Hill, 2013). Stress-induced $\mathrm{CB}_{1}$-downregulation in the hippocampus appears to involve corticosterone. The repeated administration of this glucocorticoid mimics the effects of chronic stress on $\mathrm{CB}_{1}$ receptor expression and function (Hill et al., 2008a; Bowles et al., 2012). A similar panorama is observed in rodents exposed to early-life stressful events (Suárez et al., 2009).
$\mathrm{CB}_{2}$ receptors are also modified by stress exposure. For example, early maternal deprivation increases $\mathrm{CB}_{2}$ immunoreactivity in the rat hippocampus (Suárez et al., 2009). A recent study verified that high-levels of anxiety, when combined with aversive factors (fear conditioning or exercise), increases $\mathrm{CB}_{2}$ receptor gene expression in the hippocampus. The opposite is also true: decreased anxiety (measured by escape response) was associated with reduced $\mathrm{CB}_{2}$ gene expression (Robertson et al., 2017). In mice, overexpressing $\mathrm{CB}_{2}$ receptors decreases anxiety-like behaviors, which is partially explained by changes in hippocampal $\mathrm{GABA}_{\mathrm{A}}$ receptors (García-Gutiérrez and Manzanares, 2011).

\section{Interplay between Glucocorticoids and Cannabinoid Neurotransmission}

Considering that stress-induced HPA axis activation and consequent corticosterone release modulate the production of $\mathrm{eCB}$ and $\mathrm{CB}_{1}$ function (Hillard et al., 2016), it is possible that cannabinoids and glucocorticoids interact to control stress responses. Glucocorticoid hormones and their receptors (mineralocorticoid-MR and glucocorticoid receptors-GR) are abundantly expressed in the hippocampus (Herman et al., 1993), where, together with eCBs, they control the negative feedback regulation of the HPA axis (Hillard et al., 2016). Several pieces of evidence indicate that glucocorticoids and the eCB system interact to control emotional, physiological, and adaptive responses to stress. However, the precise mechanisms involved in the cross-talk between these systems within the hippocampus are not entirely understood (Hill and Tasker, 2012).

Stress and glucocorticoids induce endocannabinoid synthesis, which in turn can act to limit HPA axis-induced changes in the brain fear circuitry (amygdala-hippocampal-cortico-striatal circuit; Steiner and Wotjak, 2008; de Oliveira Alvares et al., 2010; Hill et al., 2011b; Wang et al., 2012). The basolateral nucleus of the amygdaloidal complex (BLA) participates in the regulation of the HPA axis. Interesting, in the BLA, AEA contributes to eCB tonic signaling, which is disrupted in rodents submitted to stressbased protocols presenting high serum levels of corticosterone (Ganon-Elazar and Akirav, 2009; Hill et al., 2009, 2011b; Wang et al., 2012).

A stressful situation or corticosterone administration cause endocannabinoid-mediated suppression of GABAergic transmission in the hippocampus (Wang et al., 2012). In this forebrain structure, activation of GR receptors facilitates 2-AG-mediated neuromodulation. After repeated presentation of chronic homotypic stressors (e.g., chronic restraint stress), 2-AG levels progressively increased in the hippocampus (Hill and Tasker, 2012). Thus, it is reasonable to suggest that, in this condition, 2-AG contributes to stress adaptations induced by HPA axis activation (Hill et al., 2010; Dubreucq et al., 2012). In the prefrontal cortex, 2-AG-mediated activation of $\mathrm{CB}_{1}$ receptors located in GABAergic terminals facilitates HPA axis negative feedback (Hill et al., 2011b; Radley and Sawchenko, 2011; Wang et al., 2012). Decreased GABA release induced by $\mathrm{CB}_{1}$ stimulation in this brain area would facilitate the activation of cortical glutamatergic neurons. These latter neurons would 
signal to GABAergic interneurons located in the bed nucleus of the stria terminalis (BNST), which ultimately inhibit the secretion of the corticotrophin release hormone $(\mathrm{CRH})$ in the PVN. Although not yet investigated, it is possible that a similar phenomenon occurs in the hippocampus, since a significant part of $\mathrm{CB}_{1}$ receptors expressed there are located in GABAergic terminals (Tsou et al., 1998).

On the other hand, some studies suggest a possible biphasic effect of glucocorticoid signaling in the eCB system (Hill et al., 2008a; Wang et al., 2012; Reich et al., 2013). Administration of WIN55, 212-2 (non-selective cannabinoid agonist) prevented the trauma-induced behavioral impairments and normalized the expression of $\mathrm{CB}_{1}$ and GRs receptors in the hippocampus $\left(\mathrm{CA}_{1}\right.$ subfield; Korem and Akirav, 2014). Likewise, the same group found that intrahippocampal (into the ventral subiculum area) and intra-BLA injections of WIN55, 212-2 prevented stress-induced impairments in fear extinction retention, an effect blocked by a GRs antagonist. These results reinforce the notion that eCBs and glucocorticoids interact in these two brain structures during stressful situations (Ganon-Elazar and Akirav, 2013). The balance between these two systems, therefore, could be crucial for stress-coping mechanisms. Corroborating this proposal, Eldridge and Landfield (1990) reported that adrenalectomized rats treated for 14 days with THC, a partial agonist of $\mathrm{CB}_{1}$ receptors, presented down-regulation of hippocampal GR binding, a similar result induced by the administration of high doses of glucocorticoid.

\section{STRESS INDUCES CHANGES IN CANNABINOID-MEDIATED HIPPOCAMPAL NEUROPLASTICITY}

Probably reflecting its role in several brain functions such as learning, memory and affective processing, the hippocampus is a very plastic brain structure. One of the primary mechanisms of synaptic plasticity, particularly relevant to learning and memory, is the phenomena of long-term potentiation (LTP; Morris et al., 1986). It was first identified in the perforant pathway of the hippocampus (Lomo, 1966), and was further characterized in the Shaffer collaterals and mossy fibers. This process, therefore, affects the synaptic strength of the tri-synaptic circuit (Alger and Teyler, 1976). Another process that modulates synaptic efficiency, the long-term depression (LTD), was characterized in hippocampal synapses shortly after the description of LTP (Lynch et al., 1977; Dunwiddie and Lynch, 1978). The changes in the hippocampal synaptic efficiency are accompanied by modifications in dendritic arbor and dendritic spines (Woolley et al., 1990; Fuchs et al., 1995; Magariños and McEwen, 1995; Engert and Bonhoeffer, 1999; Toni et al., 1999; Frick et al., 2004; Matsuzaki et al., 2004; Mehta, 2004; Monfils et al., 2004; Chen et al., 2008).

Changes in hippocampal-dependent functions (e.g., cognitive deficits, affect lability and dysregulated pattern separation) are common symptoms in psychiatric patients. They are also a frequent phenotype observed in animal models of psychiatric disorders, including major depressive and anxiety disorders, schizophrenia and addiction (David et al., 2010; Christian et al., 2014; Kang et al., 2016). These symptoms could be indicative of a disrupted neuroplasticity mechanisms, such as adult newly generated neurons and atrophy of dendritic arbor of the mature neurons (Yun et al., 2016). Indeed, a decrease in hippocampal size has been considered a cellular substrate of major depression (Sheline, 1996; Duman et al., 2000; Kempermann and Kronenberg, 2003), posttraumatic stress disorder (Kitayama et al., 2005; Karl et al., 2006) and schizophrenia (Goldman and Mitchell, 2004).

The integrity of the machinery responsible for neuroplasticity seems crucial for the proper acquisition of stress coping responses (Snyder et al., 2011; Canal et al., 2014; Sinha et al., 2016; for review, see Levone et al., 2015; McEwen et al., 2015). Stress exposure, however, can also induce maladaptive changes that might contribute to the negative outcomes of chronic stress, such as learning and memory deficits, anxiogenesis, and changes in stress-coping behaviors (Willner et al., 1992; D’Aquila et al., 1994; Luine et al., 1994). For example, Foy et al. (1987) demonstrated that stress impairs hippocampal LTP induction in the $\mathrm{CA}_{1}$ region, whereas Watanabe et al. (1992) showed that repeated restraint stress for 21 days reduces dendritic branching of CA3 pyramidal neurons. Additionally, the neuroplastic hypothesis of depression and the mechanisms antidepressant drugs is heavily supported by studies using chronic stress. Selective serotonin reuptake inhibitors or tricyclic antidepressants reverse or prevent stress neuroplastic outcomes such as decreased adult hippocampal neurogenesis, dendritic arborization and spine density, and deficits in BDNF production in hippocampal and cortical neurons (Smith et al., 1995; Magariños et al., 1996; Czéh et al., 2002; Pham et al., 2003). The time-course of these antidepressant neuroplastic consequences correlates well with the latency needed for the therapeutical effects of these drugs (Santarelli et al., 2003; Bessa et al., 2008).

Adult hippocampal neurogenesis describes a stress-vulnerable process (Gould et al., 1997; Czéh et al., 2002; Pham et al., 2003; Heine et al., 2004) that gives birth to new granular cells. These cell are incorporated into the local circuitry, connecting the dentate gyrus to the CA3 region through the mossy fibers (Kempermann et al., 2015). This process has been implicated in learning and memory (Gould et al., 1999; for a review, see Kempermann, 2002), and behaviors related to anxiety and depression (Sapolsky, 2004; Revest et al., 2009). Attenuation of hippocampal neurogenesis induces anxiety- and behaviordespair in rodents (Liu et al., 2008; Revest et al., 2009; Jenniches et al., 2016). Adult hippocampal neurogenesis has been suggested to buffer the stress response (Snyder et al., 2011; Campos et al., 2013) and is implicated in the therapeutic effect of antidepressants (Santarelli et al., 2003; Malberg, 2004; David et al., 2009). Of note, structural changes observed in the hippocampus after stress response can be attenuated or reversed by antidepressants, atypical antipsychotics and physical exercise, which are known to positively impact hippocampal neurogenesis (Kempermann et al., 2010; Erickson et al., 2011).

The role of the eCBS in the fine-tuning of excitatory and inhibitory neurotransmissions makes it a very relevant modulator of neuroplasticity (den Boon et al., 2015; Song et al., 
2015). In the 1970s, some lines of evidence began to suggest that THC could interfere in the release of neurotransmitters such as GABA, serotonin, noradrenaline and excitatory amino acids (Ho et al., 1971; Sklenovský et al., 1974; Banerjee et al., 1975; Mahfouz et al., 1975). Nowicky et al. (1987), showed that THC has a biphasic effect in the duration of LTP in rat hippocampal slices, with lower concentrations increasing and higher concentrations decreasing the duration of LTP. During the following years, the existence of the eCBS was revealed to the world, and several studies started investigating its role in neuroplastic responses. Terranova et al. (1995) showed that AEA inhibits the induction of LTP in the $\mathrm{CA}_{1}$ region, an effect abolished by a $\mathrm{CB}_{1}$ receptor antagonist. Stella et al. (1997) evidenced a similar $\mathrm{CB}_{1}$-dependent effect of 2-AG. Additionally, Paton et al. (1998) and Misner and Sullivan (1999) showed that cannabinoid receptor activation resulted, respectively, in a higher paired-pulse depression and reduced frequency, but not amplitude, of miniature excitatory post-synaptic currents in $\mathrm{CA}_{1}$ neurons. Altogether, these results indicated that the cannabinoid receptor activation directly interferes with the pre-synaptic release of neurotransmitters. These discoveries contributed to the attribution of two phenomena of short-term synaptic plasticity, depolarizationinduced suppression of inhibition (DSI) and depolarizationinduced suppression of excitation (DSE), to the retrograde signaling mediated by eCBs (Kreitzer and Regehr, 2001; Wilson and Nicoll, 2001; Wilson et al., 2001).

A form of LTD is also dependent on endocannabinoid signaling, as evidenced by Marsicano et al. (2002) in the amygdala, and by Chevaleyre and Castillo (2003) in hippocampal synapses. This effect is dependent on the cAMP/PKA pathway (Chevaleyre et al., 2007). Additionally, Chávez et al. (2010) have shown that AEA induces LTD in the dentate gyrus in a TRPV1 receptor-dependent manner. Wang W. et al. (2017) showed that the activation of $\mathrm{CB}_{1}$ receptors modulates the synaptic responses of hippocampal pathways in different ways. In the Schaffer Commissural pathway, $\mathrm{CB}_{1}$ activation decreased excitatory post-synaptic potential and impaired LTP induction via an ERK1/2-MUNC18-1-dependent neurotransmitter release. In the lateral perforant pathway, however, $\mathrm{CB}_{1}$ activation leads to a FAK/ROCK2-dependent signaling that, through a $\beta$-integrin cooperative action, affects the actin dynamics needed to stabilize the synaptic potentiation. Besides depending on the signaling pathway activated, the cannabinoid-mediated plasticity is also time-dependent. For example, sub-threshold dosages of $\mathrm{CB}_{1}$ agonists, that acutely do not affect, increase the phosphorylation of the transcription factor cAMP response element bindingprotein (CREB) after chronic administration (Isokawa, 2009).

$\mathrm{CB}_{2}$ receptor deletion in mice reduced dendritic spines, impaired LTP and decreased excitatory neurotransmission (Kim and Li, 2015; Li and Kim, 2016). On the other hand, $\mathrm{CB}_{1}$ knockout (KO) mice presented a depressive-like phenotype, which was accompanied by decreased BDNF levels in the hippocampus (Aso et al., 2008). Jin et al. (2004) also showed that hippocampal neurogenesis was impaired in $\mathrm{CB}_{1} \mathrm{KO}$ mice, data corroborated by Aguado et al. (2005, 2007). Wolf et al. (2010) further supported the involvement of eCBS in regulating neurogenesis by showing that running and environmental enrichment, two pro-neurogenic stimuli, increase the hippocampal levels of the $\mathrm{CB}_{1}$ receptor. The pro-proliferative effect of running and the pro-survival effect of environmental enrichment in the neurogenic process were absent in $\mathrm{CB}_{1} \mathrm{KO}$ mice. Jiang et al. (2005) showed that the cannabinoid drug HU210 exerted pro-proliferative actions through the activation of the $\mathrm{CB}_{1}$ ERK1/2 signaling in the dentate gyrus of the hippocampus. There is also evidence for a role of $\mathrm{CB}_{2}$ receptors in controlling the phenomena of adult neurogenesis (Palazuelos et al., 2006, 2012; Goncalves et al., 2008).

Cannabinoids also prevent the neuroplastic events triggered by stress. Exposure to predator odor decreased the proliferative rate of neural stem cells located in the dentate gyrus, an effect inhibited by the treatment with the endocannabinoid uptake inhibitor AM404, but not by the concomitant treatment with AM404 and the $\mathrm{CB}_{1}$ antagonist AM251 (Hill et al., 2006). Campos et al. (2013) found that mice exposed to CUS for 14 days presented a reduced labeling for the proliferative marker 5-bromo-2'-deoxyuridine (BrdU) and doublecortin expression, a marker of immature neurons, in the dentate gyrus, supporting an anti-neurogenic action of stress. Repeated treatment with cannabidiol, a non-psychotomimetic compound of Cannabis sativa, counteracted these stress outcomes.

Similarly, the MAGL inhibitor, JZL184, reversed the effects of chronic stress in adult neurogenesis and blocked the stressinduced impairment of LTP induction in the lateral perforant pathway (Zhang et al., 2015). Furthermore, Shoshan et al. (2017) evidenced that the $\mathrm{CB}_{1} / \mathrm{CB}_{2}$ agonist WIN55-212, 2 and the FAAH inhibitor URB597 partially blocked the impairment of LTP induction in the $\mathrm{CA}_{1}$ region of rats after exposure to a severe stressful event. Besides, the antidepressant-like action of the FAAH inhibitor PF3845 in mice facing an acute stress seems to be dependent on the induction of LTD in glutamatergic synapses of the Shaffer collaterals (Wang and Zhang, 2017). In addition to interfering with glutamatergic synapses, cannabinoid drugs might also affect stress responses in GABAergic and serotonergic synapses (Bambico et al., 2012, 2016; Wang Y. et al., 2017).

Concerning the signaling pathways involved in the effects of cannabinoid drugs in stress-related neuroplasticity, the mechanistic (or mammalian) target of rapamycin (mTOR) protein has been implicated in synaptogenesis, proliferative processes, and synaptic strength modulation (Li et al., 2010; Ma et al., 2010; Romine et al., 2015; Liang et al., 2016). Some studies showed that different paradigms of stress exposure reduce mTOR activity (Iiu et al., 2016; Xia et al., 2016; Zhuang et al., 2016; Seo et al., 2017), and cannabinoid drugs can interfere with this signaling pathway (Puighermanal et al., 2009; Palazuelos et al., 2012; Gobira et al., 2015; Giacoppo et al., 2017). For example, Zhong et al. (2014) demonstrated that the antidepressant-like responses trigged by JZL184, an inhibitor of 2-AG hydrolysis, in chronically stressed mice were dependent on mTOR signaling.

Stress changes endocannabinoid signaling and the modulation of neuroplastic changes. Reich et al. (2013) found that in adolescent rats exposed to chronic mild stress, $\mathrm{CB}_{1}$ activation facilitates $\mathrm{CA}_{1}$ excitatory transmission. However, in non-stressed rats, $\mathrm{CB}_{1}$ activation reduced the excitatory 
post-synaptic currents. In addition, Talani et al. (2016) mimicked the effects of food restriction on glutamate release, LTP induction, and BDNF release in the hippocampus, by blocking $\mathrm{CB}_{1}$ receptors. $\mathrm{Hu}$ et al. (2011) showed that rats exposed to chronic restraint stress presented an impaired endocannabinoidmediated DSI in the $\mathrm{CA}_{1}$ pyramidal neurons of the dorsal hippocampus. Similar alterations in endocannabinoid-mediated plasticity were reported in other brain regions, such as the amygdala, habenula, striatum and the BNST (Rossi et al., 2008; Patel et al., 2009; Glangetas et al., 2013; Di et al., 2016; Park et al., 2017).

Notably, a recent work reported that chronic low doses of THC restored cognitive function in old mice by enhancing the expression of synaptic marker proteins and increasing hippocampal spine density. In old mice, THC treatment restored hippocampal gene transcription, an effect critically dependent on glutamatergic $\mathrm{CB}_{1}$ receptors and histone acetylation (BilkeiGorzo et al., 2017).

Taken together, the data presented here suggested that the eCBS buffers stress responses in the hippocampus by preventing stress-induced changes in neuroplasticity.

\section{STRESS-INDUCED MODULATION OF THE eCB SIGNALING IN THE HIPPOCAMPUS: IMPLICATIONS FOR STRESS COPING AND DEFENSIVE BEHAVIORS}

A large number of pharmacological and genetic studies support the proposal that the $\mathrm{eCB}$ system is an essential regulator of cognition, mood and anxiety (for review, see Ruehle et al., 2012; Hill and Patel, 2013). Stressful experiences have been associated with the precipitation of psychiatric disorders and, as discussed above, cannabinoids play a pivotal role in the regulation of behavioral responses to stressful challenges (Patel et al., 2009). Impairment of $\mathrm{CB}_{1}$ signaling induces a moderate increase in anxiety-responses under basal conditions (Haller et al., 2004b). Other studies, however, using $\mathrm{CB}_{1}$ receptor-deficient animals or $\mathrm{CB}_{1}$ antagonist, revealed increased defensive responses only under high aversive conditions (Haller et al., 2004a; de Oliveira Alvares et al., 2005; Jacob et al., 2009). Under challenging environments, a significant enhancement of emotional responses induced by stress is also found after $\mathrm{CB}_{1}$ receptor blocked (Hill et al., 2011a; Gamble-George et al., 2013). Despite these findings, contradictory data also exist. These contradictions probably reflect the already discussed stress-dependent plasticity of the $\mathrm{eCB}$ system and the localization of $\mathrm{CB}_{1}$ receptors in distinct subpopulations of GABAergic and glutamatergic neurons. Several observations indicate that GABAergic and glutamatergic neurotransmissions have opposite actions on anxiety responses (Millan, 2003).

In the hippocampus, the effects of cannabinoids are also complex and often depend on the aversiveness of the task and the doses of drugs being tested. $\mathrm{CB}_{1}$ receptor agonists usually promote biphasic effects, with lower doses being anxiolytic (Zarrindast et al., 2010) while higher doses induce no effects or even anxiogenic responses (Roohbakhsh et al., 2007). In the same way, injections of THC into the ventral hippocampus or prefrontal cortex induce anxiolytic- and anxiogenic-like effects at low and high doses, respectively (Rubino et al., 2008). Laaris et al. (2010) suggest that these biphasic effects depend on THC binding to $\mathrm{CB}_{1}$ receptors present in GABAergic or glutamatergic synapses.

Exposure-based therapy, which relies on extinction processes after repeatedly exposing the patient to stimuli associated with a traumatic, fear-related memory, is a therapeutic approach used to treat anxiety disorders. Several studies indicate that the eCBs modulate fear memory (Marsicano et al., 2002; Morena et al., 2014), and THC prevents the recovery of fear memory (Rabinak et al., 2013). In rats submitted to contextual fear conditioning, a stress-induced learned fear paradigm, intradorsal hippocampus injections of the $\mathrm{CB}_{1}$ antagonist/inverse agonist AM251, facilitated fear expression (freezing behavior + autonomic responses, Spiacci et al., 2016). Interestingly, both the freezing behavior and autonomic responses were attenuated by previous intra-hippocampal administration of the antagonist of NMDA receptors, AP7 (Spiacci et al., 2016), suggesting that AM251 effects are being mediated by facilitation of glutamate release.

Rodents trained under a high arousal condition showed increased levels of AEA in the amygdala, medial prefrontal cortex (mPFC) and hippocampus, brain regions closely associated with fear conditioning (Morena et al., 2014). The FAAH inhibitor URB597 enhanced memory consolidation/retention when infused into these brain areas; an effect prevented by a $\mathrm{CB}_{1}$ antagonist (Morena et al., 2014). Microinjection of the $\mathrm{CB}_{1} / \mathrm{CB}_{2}$ agonist WIN55, 212-2 or an inhibitor of eCB reuptake (AM404) into the $\mathrm{CA}_{1}$ facilitated the extinction process of fear memory by impairing spatial learning and LTP formation. Both effects were also prevented by previous treatment with a $\mathrm{CB}_{1}$ receptor antagonist (Abush and Akirav, 2010). In contrast, de Oliveira Alvares et al. (2010) verified that a prior stressful experience or dexamethasone injection facilitated memory consolidation in a weak conditioning protocol, an event prevented by intrahippocampal injection of AM251. However, intrahippocampal infusion of the $\mathrm{CB}_{1}$ antagonist failed to abolish the disruptive effect of norepinephrine on memory retrieval (Atsak et al., 2012).

The inhibition of AEA uptake by AM404 attenuated predator scent-induced activation of defensive burying and suppression of cell proliferation in the hippocampus (Hill et al., 2006). However, the administration of AM404 into the ventral portions of the hippocampus produced opposite effects depending on previous stressful experience. Campos et al. (2010) observed that in non-stressed mice submitted to the elevated plus maze (EPM), an ethological based animal model largely used for the screening of putative anti-anxiety compounds, AM404 induces anxiogenic-like effects. However, the same dose produced anxiolytic-like effects in rats that had been previously $(24 \mathrm{~h})$ submitted to a 2-h protocol of restraint stress. It also decreased anxiety in the Vogel Conflict Test (VCT), a model based on punished-conflict induced by $24 \mathrm{~h}$ water deprivation (Campos et al., 2010). Of note, both the anxiolytic and anxiogenic 
responses were attenuated by AM251. It had been previously demonstrated that chronic stress impairs $\mathrm{CB}_{1}$ receptor-mediated short-term plasticity at GABAergic synapses in the hippocampus (Hu et al., 2011). To explain these results, the authors hypothesized that the anxiogenic-like behavior in the EPM observed in naïve rats could be due the activation the $\mathrm{CB}_{1}$ receptors on GABAergic terminals. The previous exposure to stressors (restraint and water deprivation) could down-regulate $\mathrm{CB}_{1}$ receptors located in GABAergic terminals, facilitating $\mathrm{CB}_{1}$ mediated attenuation of glutamate release and resulting in an anxiolytic response (Campos et al., 2010; Ruehle et al., 2012). It is also possible that stress reduces GABAergic control over hippocampal projection neurons, impairing its control over the HPA axis. However, these stress-dependent effects of AEA in the ventral hippocampus do not seem to extend to its dorsal region, since URB597 and AM404 induced anxiolytic-like effects independent of previous stress experience (Hakimizadeh et al., 2012; Lisboa et al., 2015).

Concerning 2-AG signaling, the genetic deletion of DAGL adversely affects the emotional state of animals. DAGL KO mice present a marked decreased in 2-AG levels in several brains areas, including the hippocampus, together with reduced hippocampal neurogenesis (Jenniches et al., 2016). Accordingly, inhibition of 2-AG signaling in hippocampal glutamatergic neurons by genetic overexpression of MAGL leads to decreased 2-AG levels and increased anxiety-like behavior, but no change in aversive memory formation (Guggenhuber et al., 2015).

Regarding the $\mathrm{CB}_{2}$ receptor, its overexpression in mice increases resistance to anxiogenic-like stimuli and modifies $\mathrm{GABA}_{\mathrm{A}}$ receptors in the hippocampus and amygdala (GarcíaGutiérrez and Manzanares, 2011). On the other hand, acute administration of a $\mathrm{CB}_{2}$ antagonist induced anxiogenic effect, whereas chronic pharmacological blockade of this receptor produced anxiolytic effects associated with increased expression of the $\mathrm{CB}_{2}$ and the main anxiolytic subunits of $\mathrm{GABA}_{\mathrm{A}}$ receptors $\left(\alpha_{2}\right.$ and $\gamma_{2}$ subunits) genes in the amygdala and the cortex. Conversely, the protein expression of these receptors was reduced in the same brain areas (García-Gutiérrez et al., 2012). The picture, however, may be more complicated, since the protein expression of these receptors was reduced in the same brain areas (García-Gutiérrez et al., 2012).

In slices of entorhinal cortex-hippocampal, Morgan et al. (2009) showed a suppression of GABAergic inhibitory signaling following the administration of the $\mathrm{CB}_{2}$ receptor agonist, JWH133, an effect reversed by $\mathrm{AM} 630, \mathrm{CB}_{2}$ receptor inverse agonist. However, the precise mechanism involved in $\mathrm{CB}_{2}$ induced change in GABAergic neurotransmission remains to be fully elucidated. One possible speculation is that $\mathrm{CB}_{2}$ is functionally (and more) expressed in presynaptic GABAergic neurons $\left(\mathrm{CB}_{1}\right.$ - like function). Therefore, chronic administration of $\mathrm{CB}_{2}$ antagonist would increase the probability of GABA release. On the other hand, but in the same line of thought, after acute blocked, $\mathrm{CB}_{2}$ could disturb the balance between GABAergic and glutamatergic neurotransmission or induce the production of other non-classic neurotransmitters such as nitric oxide. In fact, after focal brain injury, the $\mathrm{CB}_{2}$ receptor agonist JWH-015 enhances the expression of the neuronal nitric oxide synthase (nNOS) enzyme (Oddi et al., 2012). In the hippocampus, inhibition of nNOS induces antidepressant-like effects (Joca and Guimarães, 2006; Hiroaki-Sato et al., 2014), and genes related to nitric oxide effects have been associated with posttraumatic stress disorder, major depressive disorder and anxiety (Bruenig et al., 2017).

On the topic of mood disorders, suppression of endocannabinoid signaling in the hippocampus is sufficient to induce a depressive-like state (Hill and Gorzalka, 2005; Hill et al., 2008b; Dubreucq et al., 2012; Valverde and Torrens, 2012). Impairment of $\mathrm{CB}_{1}$ receptor signaling resulted in increased immobility (passive coping behavior) in animal models used for the screening of antidepressant drugs, such as the tail suspension (TST) and the forced swimming (FST) tests. Moreover, increased HPA axis activity following exposure to stress is also reported after $\mathrm{CB}_{1}$ receptors signaling blocked (Aso et al., 2008). Chronic pharmacological activation of $\mathrm{CB}_{1}$ receptors by HU-210 induces anxiolytic and antidepressant effects and facilitates adult hippocampal neurogenesis (Jiang et al., 2005). Likewise, local activation of $\mathrm{CB}_{1}$ receptors within the dentate gyrus of the hippocampus elicited antidepressant-like behavior in socially isolated animals (McLaughlin et al., 2007). Of note, Wistar Kyoto (WKY) rat, a well-accepted model of depressive-like behavior, expresses high levels of $\mathrm{CB}_{1}$ receptors in the hippocampus. This increase of $\mathrm{CB}_{1}$ receptor binding sites could be a compensatory mechanism in response to diminished AEA tone in the hippocampus (Vinod et al., 2012). As with other cannabinoid effects discussed so far, there is also at least one contradictory result, with both THC and rimonabant $\left(\mathrm{CB}_{1}\right.$ antagonist/inverse agonist) reducing immobility time in in FST after intraperitoneal injections (Häring et al., 2013).

In the case of $\mathrm{CB}_{2}$ receptors, few data are available, and the results are not always consistent. In an animal model based on the surgical removal of the olfactory bulbs (bulbectomy-an animal model of depression), decreased levels of AEA and $\mathrm{CB}_{2}$ expression in the hippocampus were reported (Smaga et al., 2017). Furthermore, overexpression of $\mathrm{CB}_{2}$ receptors induced a depression-resilient phenotype after chronic stress, but no alterations in hippocampal BDNF levels. However, in wild-type animals submitted to CUS, acute and chronic treatment with $A M 630$, a $C_{2}$ receptor antagonist, prevented stress-induced depressive-like behaviors and decreased expression of $\mathrm{CB}_{2}$ and BDNF in the hippocampus (García-Gutiérrez et al., 2010).

Chronic stress produces behavioral and neurochemical changes in rodents that resemble those found in human depression. As we have already mentioned, chronic heterotypic stress (chronic mild/unpredictable/varied stress) reduces the hippocampal levels of AEA, 2-AG, $\mathrm{CB}_{1}$ and $\mathrm{CB}_{2}$ receptors (Hill and Gorzalka, 2005; Hill et al., 2008b; Reich et al., 2009; GarcíaGutiérrez et al., 2010; Zhong et al., 2014), and increases FAAH protein expression (Reich et al., 2009).

CUS induced depressive-like behavior, reduced hippocampal activation of mTOR signaling, decreased neurogenesis and impaired LTP induction in the hippocampus, whereas repeated injections of a MAGL inhibitor prevented CUS-induced biochemical, cellular and behavioral abnormalities (Zhong et al., 
2014; Zhang et al., 2015). Recently Wang Y. et al. (2017) found that low-doses of MAGL inhibitors prevented the acute stress-induced decrease of sucrose consumption through astrocyte-mediated LTD at CA3-CA $\mathrm{CA}_{1}$ glutamatergic synapses mechanism. On the other hand, in chronically stressed mice, low doses of MAGL inhibitors induced "pro-depressive" effects whereas high-doses produced significant anti-anhedonia effects; both responses mediated by $\mathrm{CB}_{1}$ receptors. It is worthy to mention that, in some studies, the gene deletion or the chronic treatment with a high-dose of a MAGL inhibitor induces a pro-depressant phenotype, attributable to $\mathrm{CB}_{1}$ receptor downregulation (Schlosburg et al., 2010; Imperatore et al., 2015). Of note, $\mathrm{CB}_{1}$ receptors desensitization is not observed after treatment with low doses of MAGL inhibitors (Feliszek et al., 2016), and other studies indicate that 2-AG signaling is a critical regulator of emotional behavior, particularly after exposure to stressful stimuli. Also, DAGL-deficient mice or other manipulations that reduce 2-AG signaling in the hippocampus increased behavioral despair and reduced hippocampal neurogenesis in mice (Jenniches et al., 2016).

In the case of AEA, genetic or pharmacological inhibition of FAAH seems to produce antidepressant-like effects (Hill et al., 2009; Bambico et al., 2010). A single injection of a FAAH inhibitor decreased passive behavioral coping responses to acute inescapable stress but failed in producing an antidepressant effect in chronically stressed mice (Xu et al., 2017). Additionally, in WYK rats, repeated treatment with a FAAH inhibitor induced antidepressant-like effect and increased levels of BDNF and AEA in the hippocampus (Vinod et al., 2012). Furthermore, manipulations of the CB system (FAAH KO mice and prolonged treatment with THC) increased the firing rate of dorsal raphe nucleus neurons and enhanced hippocampal 5- $\mathrm{HT}_{1 \mathrm{~A}}$ receptor activity, all hallmarks of classical antidepressant mechanism of action (Bambico et al., 2010, 2012). A recent study from the same group found that repeated treatment with a FAAH inhibitor or citalopram also modified the functional states of $5-\mathrm{HT}_{\mathrm{A}}$ and $5-\mathrm{HT} 2 \mathrm{~A} / \mathrm{C} /$ receptors in the hippocampus (Bambico et al., 2016).

Finally, it has been suggested that the available treatments for major depressive disorder modulate cannabinoid signaling (Bambico et al., 2009; Gorzalka and Hill, 2009). Similar to the actions of conventional antidepressants, both exogenous cannabinoids and eCBs seem to regulate serotonergic and noradrenergic systems. Muntoni et al. (2006) have shown that the acute intravenous injection of WIN55212-2 or $\triangle 9$-THC increased the firing rate of noradrenergic neurons in the locus coeruleus, while a single administration of the $\mathrm{CB}_{1}$ antagonist SR141716A had the opposite effect. Moreover, the inhibition of anandamide hydrolysis by URB597 in rats submitted to an acute swim stress procedure resulted in increased release of noradrenaline in the prefrontal cortex and the basolateral amygdala (Bedse et al., 2015). Gobbi et al. (2005) described that in rats the antidepressant-like activity of acute and chronic URB597 treatment were accompanied by an increase in the firing rate of serotonergic neurons in the dorsal raphe nucleus. In mice lacking the FAAH enzyme, an increased firing rate of serotonergic neurons accompanied by desensitization of inhibitory serotonergic receptors in the hippocampus was reported (Bambico et al., 2010). Similar results were reported by Bambico et al. (2016), that also described a desensitized state of 5-HT2A/C and 5-HT1A receptors in the hippocampus following URB597 treatment. An interrelationship between conventional antidepressants and cannabinoids also come from the similarity of their neuroplastic effects, with both affecting synaptic plasticity, neurogenesis and neurotrophin expression in the hippocampus (Aguado et al., 2005; Jiang et al., 2005; Campos et al., 2015; Zhang et al., 2015).

\section{eCBS AND HIPPOCAMPAL-DEPENDENT LEARNING AND MEMORY TASK}

Emotional learning is essential for survival. Stress and arousal events activate neurobiological systems that play a crucial role in memory consolidation, ensuring that the strength of memories occurs according to their emotional significance (McGaugh, 2015). Cannabinoids can modulate the different phases of memory processes, namely acquisition, consolidation, retrieval, reconsolidation and extinction ( $\mathrm{Da}$ and Takahashi, 2002; de Oliveira Alvares et al., 2008a,b; Wise et al., 2009; Abush and Akirav, 2010; Santana et al., 2016). For instance, THC impaired the performance of rodents in a working memory task and the acquisition of spatial learning in the water maze, whereas consolidation and retrieval of a previously learned task were not affected. Pre-treatment with a $\mathrm{CB}_{1}$ receptor antagonist prevented these learning deficits (Da and Takahashi, 2002). Intrahippocampal injection of a $\mathrm{CB}_{1}$ antagonist completely attenuated the memory disruption effect of THC (Wise et al., 2009). Additionally, THC activation the $\mathrm{CB}_{1}$ receptors (found mainly in GABAergic interneurons) stimulated the mTOR pathway in the hippocampus through a glutamatergic mechanism, which could be responsible for the characteristic long-term memory impairment induced by cannabinoids (Puighermanal et al., 2009).

Similar to the anxiety data, it seems that the degree of aversiveness is a crucial contributor to the influence of cannabinoid signaling on memory processes (for review, see Morena and Campolongo, 2014). Regarding memory acquisition, systemic injection of an AEA transport inhibitor (AM404) modified cognitive parameters depending on the level of emotional arousal. In a high aversive condition the drug impaired the memory acquisition of the novel object in a recognition task while, in a lower stressful environment, AM404 did not reduce memory performance (Campolongo et al., 2012). Additionally, acute administration of WIN55, 212-2 disrupted the acquisition of contextual-fear conditioning, which is a hippocampal-dependent learning and memory task (Pamplona et al., 2006). On the other hand, regarding memory consolidation, Morena et al. (2014) demonstrated that infusion of a FAAH inhibitor (URB597) into the amygdala, mPFC or hippocampus enhanced memory consolidation only in rodents trained under a high arousal condition. This effect was prevented by a $\mathrm{CB}_{1}$ antagonist. Indeed, intrahippocampal infusion of a $\mathrm{CB}_{1}$ receptor 
antagonist disrupted long-term memory consolidation, possibly by inhibiting LTP (de Oliveira Alvares et al., 2005, 2006).

The conflicting findings regarding the influence of cannabinoids in memory modulation could be reflecting differences on the aversiveness of the experimental conditions or the memory phase being tested (Barros et al., 2004; Pamplona et al., 2006; de Oliveira Alvares et al., 2008a, 2010; Abush and Akirav, 2010; Lin et al., 2011; Campolongo et al., 2012). For example, a $\mathrm{CB}_{1}$ antagonist injected into the hippocampus, for example, promoted contextual fear memory formation (Lin et al., 2011), impaired the aversive memory extinction process (de Oliveira Alvares et al., 2008b; Abush and Akirav, 2010), and potentiated the reconsolidation of fear memory (de Oliveira Alvares et al., 2008b). On the other hand, facilitation of $\mathrm{CB}_{1}$ receptor signaling in this brain area impaired contextual fear memory formation (Lin et al., 2011), facilitated the extinction learning process (de Oliveira Alvares et al., 2008b; Abush and Akirav, 2010), and disrupted emotional memories reconsolidation (de Oliveira Alvares et al., 2008b; Santana et al., 2016). Recently, Micale et al. (2017) also verified that the eCB uptake inhibitor AM404 facilitated safety learning through activity propagation to $\mathrm{CA}_{1}$ in a $\mathrm{CB}_{1}$-dependent manner, indicating a crucial involvement of the dorsal hippocampus in this process.

\section{CONCLUSION}

The data revised here indicate that the hippocampal eCB signaling contributes to emotional and behavioral flexibility during the exposure to aversive stimuli, functioning as a regulatory buffer system for emotional responses. eCBs are essential players in plastic events involved in the flexibility of hippocampal functions in basal conditions and during stressful situations. They also regulate the HPA axis responses to stress (Figure 2). Impairment of $\mathrm{eCB}$ signaling in the hippocampus following acute/chronic stress could contribute to the development of psychiatric disorders such as major depressive and anxiety disorders (Gorzalka et al., 2008; Lutz, 2009). Finding new eCBs molecular targets to modulate the "stressed hippocampus", therefore, could be a helpful contribution for novel therapeutic approaches. This proposal, however, has its limitations. Both cannabinoids and stress induce bell- or U-shaped dose/intensity responses, which somehow complicate data interpretation and could help to explain some of the contradictory results reported in the

\section{REFERENCES}

Abou Jamra, R., Schulze, T. G., Becker, T., Brockschmidt, F. F., Green, E., Alblas, M. A., et al. (2010). A systematic association mapping on chromosome $6 \mathrm{q}$ in bipolar affective disorder-evidence for the melanin-concentratinghormone-receptor-2 gene as a risk factor for bipolar affective disorder. Am. J. Med. Genet. B Neuropsychiatr. Genet. 153B, 878-884. doi: 10.1002/ajmg.b. 31051 literature. New systematic studies, isolating and comparing in standard conditions the behavioral and neuroplastic effects of mild/intense stressors, acute/repeated stress exposure and treatments, and low/high cannabinoid doses, are needed to elucidate the precise role of the eCBs in stress-induced brain changes.

Another critical point is that most of the available data in the literature associating hippocampus, $\mathrm{eCB}$, and stress arrive from preclinical studies and sometimes seem to depend on the animal model being used. Although stressful experiences are definite risk factors for the precipitation of psychiatric disorders, caution must be taken to translate the preclinical data directly into human pathology. Moreover, besides the hippocampus, other brain regions such as the prefrontal cortex, amygdala (Hill et al., 2010), nucleus accumbens (Bosch-Bouju et al., 2016), the paraventricular nucleus of the hypothalamus (Wamsteeker et al., 2010), lateral habenula (Park et al., 2017) and the periaqueductal gray matter (Moreira et al., 2009), are involved in stress-induced behavioral and neuroplastic consequences. These regions are modulated by eCBs and, therefore, are also potential therapeutic targets for cannabinoid drugs (For additional information about this topic, please read the excellent reviews by Gorzalka and Hill (2009), Riebe and Wotjak (2011), Hillard et al. (2016), Lutz et al. (2016) and Balsevich et al. (2017).

\section{AUTHOR CONTRIBUTIONS}

FFS, CV-V, NCF-J and VLD wrote the first version of the manuscript. FFS and $\mathrm{CV}-\mathrm{V}$ edited the first version of the text. ACC and FSG corrected and edited the final version of the manuscript. ACC and NCF-J designed the figures.

\section{FUNDING}

FFS and CV-V have CNPq fellowships; VLD has a CAPES fellowship; ACC and FSG are recipients of FAPESP research grants (2015/05551-0 and 2012/17626-7, respectively). NCF-J is a Pratti-Donaduzzi research fellowship.

\section{ACKNOWLEDGMENTS}

We thank our research group for keeping such interactive and comprehensible scientific environment. We apologize to all authors whose studies were not cited here, due to space limitations. 
neural progenitor proliferation and neurogenesis. J. Biol. Chem. 282, 23892-23898. doi: 10.1074/jbc.m700678200

Akirav, I. (2011). The role of cannabinoids in modulating emotional and non-emotional memory processes in the hippocampus. Front. Behav. Neurosci. 5:34. doi: 10.3389/fnbeh.2011.00034

Alger, B. E., and Teyler, T. J. (1976). Long-term and short-term plasticity in the $\mathrm{CA}_{1}, \mathrm{CA} 3$, and dentate regions of the rat hippocampal slice. Brain Res. 110, 463-480. doi: 10.1016/0006-8993(76)90858-1

Aso, E., Ozaita, A., Valdizán, E. M., Ledent, C., Pazos, A., Maldonado, R., et al. (2008). BDNF impairment in the hippocampus is related to enhanced despair behavior in $\mathrm{CB}_{1}$ knockout mice. J. Neurochem. 105, 565-572. doi: 10.1111/j. 1471-4159.2007.05149.x

Atsak, P., Hauer, D., Campolongo, P., Schelling, G., McGaugh, J. L., and Roozendaal, B. (2012). Glucocorticoids interact with the hippocampal endocannabinoid system in impairing retrieval of contextual fear memory. Proc. Natl. Acad. Sci. U S A 109, 3504-3509. doi: 10.1073/pnas.1200742109

Azad, S. C., Monory, K., Marsicano, G., Cravatt, B. F., Lutz, B., Zieglgansberger, W., et al. (2004). Circuitry for associative plasticity in the amygdala involves endocannabinoid signaling. J. Neurosci. 24, 9953-9961. doi: 10.1523/jneurosci.2134-04.2004

Balsevich, G., Petrie, G. N., and Hill, M. N. (2017). Endocannabinoids: effectors of glucocorticoid signaling. Front. Neuroendocrinol. 47, 86-108. doi: 10.1016/j. yfrne.2017.07.005

Bambico, F. R., Cassano, T., Dominguez-Lopez, S., Katz, N., Walker, C. D., Piomelli, D., et al. (2010). Genetic deletion of fatty acid amide hydrolase alters emotional behavior and serotonergic transmission in the dorsal raphe, prefrontal cortex, and hippocampus. Neuropsychopharmacology 35, 2083-2100. doi: $10.1038 /$ npp. 2010.80

Bambico, F. R., Duranti, A., Nobrega, J. N., and Gobbi, G. (2016). The fatty acid amide hydrolase inhibitor URB597 modulates serotonin-dependent emotional behaviour, and serotonin1 $\mathrm{A}$ and serotonin2A/C activity in the hippocampus. Eur. Neuropsychopharmacol. 26, 578-590. doi: 10.1016/j.euroneuro.2015. 12.027

Bambico, F. R., Duranti, A., Tontini, A., Tarzia, G., and Gobbi, G. (2009). Endocannabinoids in the treatment of mood disorders: evidence from animal models. Curr. Pharm. Des. 15, 1623-1646. doi: 10.2174/138161209788168029

Bambico, F. R., Hattan, P. R., Garant, J. P., and Gobbi, G. (2012). Effect of $\Delta$-9-tetrahydrocannabinol on behavioral despair and on pre- and postsynaptic serotonergic transmission. Prog. Neuropsychopharmacol. Biol. Psychiatry 38, 88-96. doi: 10.1016/j.pnpbp.2012.02.006

Banerjee, S. P., Snyder, S. H., and Mechoulam, R. (1975). Cannabinoids: influence on neurotransmitter uptake in rat brain synaptosomes. J. Pharmacol. Exp. Ther. 194, 74-81.

Barros, D. M., Carlis, V., Maidana, M., Silva, E. S., Baisch, A. L., Ramirez, M. R., et al. (2004). Interactions between anandamide-induced anterograde amnesia and post-training memory modulatory systems. Brain Res. 1016, 66-71. doi: 10.1016/j.brainres.2004.04.067

Bedse, G., Romano, A., Tempest, B., Lavecchia, M. A., Pace, L., Bellomo, A., et al. (2015). Inhibition of anandamide hydrolysis enhances noradrenergic and GABAergic transmission in the prefrontal cortex and basolateral amygdala of rats subjected to acute swim stress. J. Neurosci. Res. 93, 777-787. doi: $10.1002 /$ jnr.23539

Bessa, J. M., Ferreira, D., Melo, I., Marques, F., Cerqueira, J. J., Palha, J. A., et al. (2008). The mood-improving actions of antidepressants do not depend on neurogenesis but are associated with neuronal remodeling. Mol. Psychiatry 14, 764-773. doi: 10.1038/mp.2008.119

Bilkei-Gorzo, A., Albayram, O., Draffehn, A., Michel, K., Piyanova, A., Oppenheimer, H., et al. (2017). A chronic low dose of $\Delta 9$ tetrahydrocannabinol (THC) restores cognitive function in old mice. Nat. Med. 23, 782-787. doi: 10.1038/nm.4311

Bluett, R. J., Gamble-George, J. C., Hermanson, D. J., Hartley, N. D., Marnett, L. J., and Patel, S. (2014). Central anandamide deficiency predicts stress-induced anxiety: behavioral reversal through endocannabinoid augmentation. Transl. Psychiatry 4:e408. doi: 10.1038/tp.2014.53

Bortolato, M., Mangieri, R. A., Fu, J., Kim, J. H., Arguello, O., Duranti, A., et al. (2007). Antidepressant-like activity of the fatty acid amide hydrolase inhibitor URB597 in a rat model of chronic mild stress. Biol. Psychiatry 62, 1103-1110. doi: 10.1016/j.biopsych.2006.12.001
Bosch-Bouju, C., Larrieu, T., Linders, L., Manzoni, O. J., and Layé, S. (2016). Endocannabinoid-mediated plasticity in nucleus accumbens controls vulnerability to anxiety after social defeat stress. Cell Rep. 16, 1237-1242. doi: 10.1016/j.celrep.2016.06.082

Bowles, N. P., Hill, M. N., Bhagat, S. M., Karatsoreos, I. N., Hillard, C. J., and McEwen, B. S. (2012). Chronic, noninvasive glucocorticoid administration suppresses limbic endocannabinoid signaling in mice. Neuroscience 204, 83-89. doi: 10.1016/j.neuroscience.2011.08.048

Bruenig, D., Morris, C. P., Mehta, D., Harvey, W., Lawford, B., Young, R. M., et al. (2017). Nitric oxide pathway genes (NOS1AP and NOS1) are involved in PTSD severity, depression, anxiety, stress and resilience. Gene 625, 42-48. doi: 10.1016/j.gene.2017.04.048

Brusco, A., Tagliaferro, P. A., Saez, T., and Onaivi, E. S. (2008). Ultrastructural localization of neuronal brain $\mathrm{CB}_{2}$ cannabinoid receptors. Ann. N Y Acad. Sci. 1139, 450-457. doi: 10.1196/annals.1432.037

Campolongo, P., Ratano, P., Manduca, A., Scattoni, M. L., Palmery, M., Trezza, V., et al. (2012). The endocannabinoid transport inhibitor AM404 differentially modulates recognition memory in rats depending on environmental aversiveness. Front. Behav. Neurosci. 6:11. doi: 10.3389/fnbeh.2012.00011

Campos, A. C., Brant, F., Miranda, A. S., Machado, F. S., and Teixeira, A. L. (2015). Cannabidiol increases survival and promotes rescue of cognitive function in a murine model of cerebral malaria. Neuroscience 289, 166-180. doi: 10.1016/j. neuroscience.2014.12.051

Campos, A. C., Ferreira, F. G., Guimarães, F. S., and Lemos, J. I. (2010). Facilitation of endocannabinoid effects in the ventral hippocampus modulates anxiety-like behaviors depending on previous stress experience. Neuroscience 167, 238-246. doi: 10.1016/j.neuroscience.2010.01.062

Campos, A. C., Ortega, Z., Palazuelos, J., Fogaça, M. V., Aguiar, D. C., Díaz-Alonso, J., et al. (2013). The anxiolytic effect of cannabidiol on chronically stressed mice depends on hippocampal neurogenesis: involvement of the endocannabinoid system. Int. J. Neuropsychopharmacol. 16, 1407-1419. doi: $10.1017 / \mathrm{s} 1461145712001502$

Canal, M., Romaní-Aumedes, J., Martín-Flores, N., Pérez-Fernández, V., and Malagelada, C. (2014). RTP801/REDD1: a stress coping regulator that turns into a troublemaker in neurodegenerative disorders. Front. Cell. Neurosit. 8:313. doi: $10.3389 /$ fncel.2014.00313

Chávez, A. E., Chiu, C. Q., and Castillo, P. E. (2010). TRPV1 activation by endogenous anandamide triggers postsynaptic long-term depression in dentate gyrus. Nat. Neurosci. 13, 1511-1518. doi: 10.1038/nn.2684

Chen, Y., Dubé, C. M., Rice, C. J., and Baram, T. Z. (2008). Rapid loss of dendritic spines after stress involves derangement of spine dynamics by corticotropinreleasing hormone. J. Neurosci. 28, 2903-2911. doi: 10.1523/JNEUROSCI.022508.2008

Chevaleyre, V., and Castillo, P. E. (2003). Heterosynaptic LTD of hippocampal GABAergic synapses: a novel role of endocannabinoids in regulating excitability. Neuron 38, 461-472. doi: 10.1016/S0896-6273(03)00235-6

Chevaleyre, V., Heifets, B. D., Kaeser, P. S., Sudhof, T. C., and Castillo, P. E. (2007). Endocannabinoid-mediated long-term plasticity requires cAMP/PKA signaling and RIM1 $\alpha$. Neuron 54, 801-812. doi: 10.1016/j.neuron.2007.05.020

Choi, K., Le, T., Mcguire, J., Xing, G., Zhang, L., Li, H., et al. (2012). Expression pattern of the cannabinoid receptor genes in the frontal cortex of mood disorder patients and mice selectively bred for high and low fear. J. Psychiatr. Res. 46, 882-889. doi: 10.1016/j.jpsychires.2012.03.021

Christian, K. M., Song, H., and Ming, G. L. (2014). Functions and dysfunctions of adult hippocampal neurogenesis. Annu. Rev. Neurosci. 37, 243-262. doi: 10.1146/annurev-neuro-071013-014134

Cravatt, B. F., Giang, D. K., Mayfield, S. P., Boger, D. L., Lerner, R. A., and Gilula, N. B. (1996). Molecular characterization of an enzyme that degrades neuromodulatory fatty-acid amides. Nature 384, 83-87. doi: 10.1038/384083a0

Czéh, B., Welt, T., Fischer, A. K., Erhardt, A., Schmitt, W., Müller, M. B., et al. (2002). Chronic psychosocial stress and concomitant repetitive transcranial magnetic stimulation: effects on stress hormone levels and adult hippocampal neurogenesis. Biol. Psychiatry 52, 1057-1065. doi: 10.1016/s00063223(02)01457-9

Da, S., and Takahashi, R. N. (2002). SR 141716A prevents $\Delta$ 9tetrahydrocannabinol-induced spatial learning deficit in a Morris-type water maze in mice. Prog. Neuropsychopharmacol. Biol. Psychiatry 26, 321-325. doi: 10.1016/s0278-5846(01)00275-5 
D’Addario, C., Micale, V., Di Bartolomeo, M., Stark, T., Pucci, M., Sulcova, A., et al. (2017). A preliminary study of endocannabinoid system regulation in psychosis: distinct alterations of CNR1 promoter DNA methylation in patients with schizophrenia. Schizophr. Res. 188, 132-140. doi: 10.1016/j.schres.2017. 01.022

D'Aquila, P. S., Brain, P., and Willner, P. (1994). Effects of chronic mild stress on performance in behavioural tests relevant to anxiety and depression. Physiol. Behav. 56, 861-867. doi: 10.1016/0031-9384(94)90316-6

David, D. J., Samuels, B. A., Rainer, Q., Wang, J. W., Marsteller, D., Mendez, I., et al. (2009). Neurogenesis-dependent and -independent effects of fluoxetine in an animal model of anxiety/depression. Neuron 62, 479-493. doi: 10.1016/j. neuron.2009.04.017

David, D. J., Wang, J., Samuels, B. A., Rainer, Q., David, I., Gardier, A. M., et al. (2010). Implications of the functional integration of adult-born hippocampal neurons in anxiety-depression disorders. Neuroscientist 16, 578-591. doi: 10.1177/1073858409360281

de Oliveira Alvares, L., de Oliveira, L. F., Camboim, C., Diehl, F., Genro, B. P., Lanziotti, V. B., et al. (2005). Amnestic effect of intrahippocampal AM251, a $\mathrm{CB}_{1}$-selective blocker, in the inhibitory avoidance, but not in the open field habituation task, in rats. Neurobiol. Learn. Mem. 83, 119-124. doi: 10.1016/j. nlm.2004.10.002

de Oliveira Alvares, L., Engelke, D. S., Diehl, F., Scheffer-Teixeira, R., Haubrich, J., De Freitas Cassini, L., et al. (2010). Stress response recruits the hippocampal endocannabinoid system for the modulation of fear memory. Learn. Mem. 17, 202-209. doi: 10.1101/lm.1721010

de Oliveira Alvares, L., Genro, B. P., Diehl, F., and Quillfeldt, J. A. (2008a). Differential role of the hippocampal endocannabinoid system in the memory consolidation and retrieval mechanisms. Neurobiol. Learn. Mem. 90, 1-9. doi: 10.1016/j.nlm.2008.01.009

de Oliveira Alvares, L., Pasqualini Genro, B., Diehl, F., Molina, V. A., and Quillfeldt, J. A. (2008b). Opposite action of hippocampal $\mathrm{CB}_{1}$ receptors in memory reconsolidation and extinction. Neuroscience 154, 1648-1655. doi: 10.1016/j.neuroscience.2008.05.005

de Oliveira Alvares, L., Genro, B. P., Vaz Breda, R., Pedroso, M. F., Da Costa, J. C., and Quillfeldt, J. A. (2006). AM251, a selective antagonist of the $\mathrm{CB}_{1}$ receptor, inhibits the induction of long-term potentiation and induces retrograde amnesia in rats. Brain Res. 1075, 60-67. doi: 10.1016/j.brainres.2005. 11.101

den Boon, F. S., Werkman, T. R., Schaafsma-Zhao, Q., Houthuijs, K., Vitalis, T., Kruse, C. G., et al. (2015). Activation of type-1 cannabinoid receptor shifts the balance between excitation and inhibition towards excitation in layer II/III pyramidal neurons of the rat prelimbic cortex. Pflugers Arch. 467, 1551-1564. doi: 10.1007/s00424-014-1586-Z

Devane, W. A., Dysarz, F. A. III, Johnson, M. R., Melvin, L. S., and Howlett, A. C. (1988). Determination and characterization of a cannabinoid receptor in rat brain. Mol. Pharmacol. 34, 605-613.

Devane, W. A., Hanus, L., Breuer, A., Pertwee, R. G., Stevenson, L. A., Griffin, G., et al. (1992). Isolation and structure of a brain constituent that binds to the cannabinoid receptor. Science 258, 1946-1949. doi: 10.1126/science.1470919

Di, S., Itoga, C. A., Fisher, M. O., Solomonow, J., Roltsch, E. A., Gilpin, N. W., et al. (2016). Acute stress suppresses synaptic inhibition and increases anxiety via endocannabinoid release in the basolateral amygdala. J. Neurosci. 36, 8461-8470. doi: 10.1523/jneurosci.2279-15.2016

Dinh, T. P., Kathuria, S., and Piomelli, D. (2004). RNA interference suggests a primary role for monoacylglycerol lipase in the degradation of the endocannabinoid 2-arachidonoylglycerol. Mol. Pharmacol. 66, 1260-1264. doi: 10.1124/mol.104.002071

Dubreucq, S., Matias, I., Cardinal, P., Häring, M., Lutz, B., Marsicano, G., et al. (2012). Genetic dissection of the role of cannabinoid type-1 receptors in the emotional consequences of repeated social stress in mice. Neuropsychopharmacology 37, 1885-1900. doi: 10.1038/npp.2012.36

Duman, R. S., Malberg, J., Nakagawa, S., and D'Sa, C. (2000). Neuronal plasticity and survival in mood disorders. Biol. Psychiatry 48, 732-739. doi: 10.1016/s0006-3223(00)00935-5

Dunwiddie, T., and Lynch, G. (1978). Long-term potentiation and depression of synaptic responses in the rat hippocampus: localization and frequency dependency. J. Physiol. 276, 353-367. doi: 10.1113/jphysiol.1978. sp012239
Eldridge, J. C., and Landfield, P. W. (1990). Cannabinoid interactions with glucocorticoid receptors in rat hippocampus. Brain Res. 534, 135-141. doi: 10.1016/0006-8993(90)90123-s

Engert, F., and Bonhoeffer, T. (1999). Dendritic spine changes associated with hippocampal long-term synaptic plasticity. Nature 399, 66-70. doi: 10.1038/19978

Erickson, K. I., Voss, M. W., Prakash, R. S., Basak, C., Szabo, A., Chaddock, L., et al. (2011). Exercise training increases size of hippocampus and improves memory. Proc. Natl. Acad. Sci. U S A 108, 3017-3022. doi: 10.1073/pnas.101 5950108

Feliszek, M., Bindila, L., Lutz, B., Zimmer, A., Bilkei-Gorzo, A., and Schlicker, E. (2016). Lack of hippocampal $\mathrm{CB}_{1}$ receptor desensitization by $\Delta^{9}$-tetrahydrocannabinol in aged mice and by low doses of JZL 184. Naunyn Schmiedebergs Arch. Pharmacol. 389, 603-612. doi: 10.1007/s00210-016-1226-6

Foy, M. R., Stanton, M. E., Levine, S., and Thompson, R. F. (1987). Behavioral stress impairs long-term potentiation in rodent hippocampus. Behav. Neural Biol. 48, 138-149. doi: 10.1016/s0163-1047(87)90664-9

Frick, A., Magee, J., and Johnston, D. (2004). LTP is accompanied by an enhanced local excitability of pyramidal neuron dendrites. Nat. Neurosci. 7, 126-135. doi: $10.1038 / \mathrm{nn} 1178$

Fuchs, E., Uno, H., and Flügge, G. (1995). Chronic psychosocial stress induces morphological alterations in hippocampal pyramidal neurons of the tree shrew. Brain Res. 673, 275-282. doi: 10.1016/0006-8993(94)01424-g

Ganon-Elazar, E., and Akirav, I. (2009). Cannabinoid receptor activation in the basolateral amygdala blocks the effects of stress on the conditioning and extinction of inhibitory avoidance. J. Neurosci. 29, 11078-11088. doi: 10.1523/JNEUROSCI.1223-09.2009

Ganon-Elazar, E., and Akirav, I. (2013). Cannabinoids and traumatic stress modulation of contextual fear extinction and GR expression in the amygdalahippocampal-prefrontal circuit. Psychoneuroendocrinology 38, 1675-1687. doi: 10.1016/j.psyneuen.2013.01.014

Gamble-George, J. C., Conger, J. R., Hartley, N. D., Gupta, P., Sumislawski, J. J., and Patel, S. (2013). Dissociable effects of $\mathrm{CB}_{1}$ receptor blockade on anxiety-like and consummatory behaviors in the novelty-induced hypophagia test in mice. Psychopharmacology 228, 401-409. doi: 10.1007/s00213-0133042-8

Gaoni, Y., and Mechoulam, R. (1964). Isolation, structure, and partial synthesis of an active constituent of hashish. J. Am. Chem. Soc. 86, 1646-1647. doi: $10.1021 / \mathrm{ja} 01062 \mathrm{a} 046$

García-Gutiérrez, M. S., Garcia-Bueno, B., Zoppi, S., Leza, J. C., and Manzanares, J. (2012). Chronic blockade of cannabinoid $\mathrm{CB}_{2}$ receptors induces anxiolytic-like actions associated with alterations in $\mathrm{GABA}_{\mathrm{A}}$ receptors. Br. J. Pharmacol. 165, 951-964. doi: 10.1111/j.1476-5381.2011.01625.x

García-Gutiérrez, M. S., and Manzanares, J. (2011). Overexpression of $\mathrm{CB}_{2}$ cannabinoid receptors decreased vulnerability to anxiety and impaired anxiolytic action of alprazolam in mice. J. Psychopharmacol. 25, 111-120. doi: $10.1177 / 0269881110379507$

García-Gutiérrez, M. S., Pérez-Ortiz, J. M., Gutiérrez-Adán, A., and Manzanares, J. (2010). Depression-resistant endophenotype in mice overexpressing cannabinoid $\mathrm{CB}_{2}$ receptors. Br. J. Pharmacol. 160, 1773-1784. doi: 10.1111/j. 1476-5381.2010.00819.x

Gerdeman, G. L., Ronesi, J., and Lovinger, D. M. (2002). Postsynaptic endocannabinoid release is critical to long-term depression in the striatum. Nat. Neurosci. 5, 446-451. doi: 10.1038/nn832

Giacoppo, S., Pollastro, F., Grassi, G., Bramanti, P., and Mazzon, E. (2017). Target regulation of PI3K/Akt/mTOR pathway by cannabidiol in treatment of experimental multiple sclerosis. Fitoterapia 116, 77-84. doi: 10.1016/j.fitote. 2016.11.010

Glangetas, C., Girard, D., Groc, L., Marsicano, G., Chaouloff, F., and Georges, F. (2013). Stress switches cannabinoid type-1 $\left(\mathrm{CB}_{1}\right)$ Receptordependent plasticity from LTD to LTP in the bed nucleus of the stria terminalis. J. Neurosci. 33, 19657-19663. doi: 10.1523/jneurosci.3175-13.2013

Gobbi, G., Bambico, F. R., Mangieri, R., Bortolato, M., Campolongo, P., Solinas, M., et al. (2005). Antidepressant-like activity and modulation of brain monoaminergic transmission by blockade of anandamide hydrolysis. Proc. Natl. Acad. Sci. U S A 102, 18620-18625. doi: 10.1073/pnas.0509591102

Gobira, P. H., Vilela, L. R., Gonçalves, B. D. C., Santos, R. P. M., de Oliveira, A. C., Vieira, L. B., et al. (2015). Cannabidiol, a Cannabis sativa constituent, inhibits 
cocaine-induced seizures in mice: possible role of the mTOR pathway and reduction in glutamate release. Neurotoxicology 50, 116-121. doi: 10.1016/j. neuro.2015.08.007

Goldman, M. B., and Mitchell, C. P. (2004). What is the functional significance of hippocampal pathology in schizophrenia? Schizophr. Bull. 30, 367-392. doi: 10.1093/oxfordjournals.schbul.a007086

Goncalves, M. B., Suetterlin, P., Yip, P., Molina-Holgado, F., Walker, D. J., Oudin, M. J., et al. (2008). A diacylglycerol lipase- $\mathrm{CB}_{2}$ cannabinoid pathway regulates adult subventricular zone neurogenesis in an age-dependent manner. Mol. Cell. Neurosci. 38, 526-536. doi: 10.1016/j.mcn.2008.05.001

Gorzalka, B. B., and Hill, M. N. (2009). Integration of endocannabinoid signaling into the neural network regulating stress-induced activation of the hypothalamic-pituitary-adrenal axis. Curr. Top. Behav. Neurosci. 1, 289-306. doi: 10.1007/978-3-540-88955-7_12

Gorzalka, B. B., Hill, M. N., and Hillard, C. J. (2008). Regulation of endocannabinoid signaling by stress: implications for stress-related affective disorders. Neurosci. Biobehav. Rev. 32, 1152-1160. doi: 10.1016/j.neubiorev. 2008.03.004

Gould, E., Beylin, A., Tanapat, P., Reeves, A., and Shors, T. J. (1999). Learning enhances adult neurogenesis in the hippocampal formation. Nat. Neurosci. 2, 260-265. doi: 10.1038/6365

Gould, E., McEwen, B. S., Tanapat, P., Galea, L. A. M., and Fuchs, E. (1997). Neurogenesis in the dentate gyrus of the adult tree shrew is regulated by psychosocial stress and NMDA receptor activation. J. Neurosci. 17, 2492-2498.

Guggenhuber, S., Romo-Parra, H., Bindila, L., Leschik, J., Lomazzo, E., Remmers, F., et al. (2015). Impaired 2-AG signaling in hippocampal glutamatergic neurons: aggravation of anxiety-like behavior and unaltered seizure susceptibility. Int. J. Neuropsychopharmacol. 19:pyv091. doi: 10.1093/ijnp/pyv091

Hakimizadeh, E., Oryan, S., Hajizadeh Moghaddam, A., Shamsizadeh, A., and Roohbakhsh, A. (2012). Endocannabinoid system and TRPV1 receptors in the dorsal hippocampus of the rats modulate anxiety-like behaviors. Iran. J. Basic Med. Sci. 15, 795-802.

Haller, J., Varga, B., Ledent, C., Barna, I., and Freund, T. F. (2004a). Contextdependent effects of $\mathrm{CB}_{1}$ cannabinoid gene disruption on anxiety-like and social behaviour in mice. Eur. J. Neurosci. 19, 1906-1912. doi: 10.1111/j.14609568.2004.03293.x

Haller, J., Varga, B., Ledent, C., and Freund, T. F. (2004b). CB 1 cannabinoid receptors mediate anxiolytic effects: convergent genetic and pharmacological evidence with $\mathrm{CB}_{1}$-specific agents. Behav. Pharmacol. 15, 299-304. doi: 10.1097/01.fbp.0000135704.56422.40

Häring, M., Grieb, M., Monory, K., Lutz, B., and Moreira, F. A. (2013). Cannabinoid $\mathrm{CB}_{1}$ receptor in the modulation of stress coping behavior in mice: the role of serotonin and different forebrain neuronal subpopulations. Neuropharmacology $\quad 65, \quad 83-89$. doi: 10.1016/j.neuropharm.2012. 09.002

Heine, V. M., Maslam, S., Zareno, J., Joëls, M., and Lucassen, P. J. (2004). Suppressed proliferation and apoptotic changes in the rat dentate gyrus after acute and chronic stress are reversible. Eur. J. Neurosci. 19, 131-144. doi: 10.1046/j.1460-9568.2003.03100.x

Herman, J. P., Watson, S. J., Chao, H. M., Coirini, H., and McEwen, B. S. (1993). Diurnal regulation of glucocorticoid receptor and mineralocorticoid receptor mRNAs in rat hippocampus. Mol. Cell. Neurosci. 4, 181-190. doi: 10.1006/mcne.1993.1022

Hill, M. N., Carrier, E. J., Ho, W. S., Shi, L., Patel, S., Gorzalka, B. B., et al. (2008a). Prolonged glucocorticoid treatment decreases cannabinoid $\mathrm{CB}_{1}$ receptor density in the hippocampus. Hippocampus 18, 221-226. doi: 10.1002/hipo. 20386

Hill, M. N., Carrier, E. J., McLaughlin, R. J., Morrish, A. C., Meier, S. E., Hillard, C. J., et al. (2008b). Regional alterations in the endocannabinoid system in an animal model of depression: effects of concurrent antidepressant treatment. J. Neurochem. 106, 2322-2336. doi: 10.1111/j.1471-4159.2008. 05567.x

Hill, M. N., and Gorzalka, B. B. (2005). Is there a role for the endocannabinoid system in the etiology and treatment of melancholic depression? Behav. Pharmacol. 16, 333-352. doi: 10.1097/00008877-200509000-00006

Hill, M. N., Hillard, C. J., Bambico, F. R., Patel, S., Gorzalka, B. B., and Gobbi, G. (2009). The therapeutic potential of the endocannabinoid system for the development of a novel class of antidepressants. Trends Pharmacol. Sci. 30, 484-493. doi: 10.1016/j.tips.2009.06.006

Hill, M. N., Hillard, C. J., and McEwen, B. S. (2011a). Alterations in corticolimbic dendritic morphology and emotional behavior in cannabinoid $\mathrm{CB}_{1}$ receptordeficient mice parallel the effects of chronic stress. Cereb. Cortex 21, 2056-2064. doi: 10.1093/cercor/bhq280

Hill, M. N., McLaughlin, R. J., Pan, B., Fitzgerald, M. L., Roberts, C. J., Lee, T. T., et al. (2011b). Recruitment of prefrontal cortical endocannabinoid signaling by glucocorticoids contributes to termination of the stress response. J. Neurosci. 31, 10506-10515. doi: 10.1523/JNEUROSCI.0496-11.2011

Hill, M. N., Kambo, J. S., Sun, J. C., Gorzalka, B. B., and Galea, L. A. (2006). Endocannabinoids modulate stress-induced suppression of hippocampal cell proliferation and activation of defensive behaviours. Eur. J. Neurosci. 24, 1845-1849. doi: 10.1111/j.1460-9568.2006.05061.x

Hill, M. N., McLaughlin, R. J., Bingham, B., Shrestha, L., Lee, T. T., Gray, J. M., et al. (2010). Endogenous cannabinoid signaling is essential for stress adaptation. Proc. Natl. Acad. Sci. U S A 107, 9406-9411. doi: 10.1073/pnas.0914661107

Hill, M. N., and Patel, S. (2013). Translational evidence for the involvement of the endocannabinoid system in stress-related psychiatric illnesses. Biol. Mood Anxiety Disord. 3:19. doi: 10.1186/2045-5380-3-19

Hill, M. N., and Tasker, J. G. (2012). Endocannabinoid signaling, glucocorticoidmediated negative feedback, and regulation of the hypothalamic-pituitaryadrenal axis. Neuroscience 204, 5-16. doi: 10.1016/j.neuroscience.2011.12.030

Hillard, C. J. (2014). Stress regulates endocannabinoid- $\mathrm{CB}_{1}$ receptor signaling. Semin. Immunol. 26, 380-388. doi: 10.1016/j.smim.2014.04.001

Hillard, C. J., Beatka, M., and Sarvaideo, J. (2016). Endocannabinoid signaling and the hypothalamic-pituitary-adrenal axis. Compr. Physiol. 7, 1-15. doi: $10.1002 /$ cphy.c160005

Hillard, C. J., Weinlander, K. M., and Stuhr, K. L. (2012). Contributions of endocannabinoid signaling to psychiatric disorders in humans: genetic and biochemical evidence. Neuroscience 204, 207-229. doi: 10.1016/j.neuroscience. 2011.11.020

Hiroaki-Sato, V. A., Sales, A. J., Biojone, C., and Joca, S. R. (2014). Hippocampal nNOS inhibition induces an antidepressant-like effect: involvement of 5HT1A receptors. Behav. Pharmacol. 25, 187-196. doi: 10.1097/FBP. 0000000000000035

Ho, B. T., Taylor, D., Englert, L. F., and McIsaac, W. M. (1971). Neurochemical effects of $\mathrm{L}-\Delta^{9}$-tetrahydrocannabinol in rats following repeated inhalation. Brain Res. 31, 233-236. doi: 10.1016/0006-8993(71)90652-4

Howlett, A. C. (1985). Cannabinoid inhibition of adenylate cyclase. Biochemistry of the response in neuroblastoma cell membranes. Mol. Pharmacol. 27, 429-436.

Howlett, A. C., and Fleming, R. M. (1984). Cannabinoid inhibition of adenylate cyclase. Pharmacology of the response in neuroblastoma cell membranes. Mol. Pharmacol. 26, 532-538. doi: 10.1016/0028-3908(87)90035-9

Hu, W., Zhang, M., Czéh, B., Zhang, W., and Flügge, G. (2011). Chronic restraint stress impairs endocannabinoid mediated suppression of GABAergic signaling in the hippocampus of adult male rats. Brain Res. Bull. 85, 374-379. doi: 10.1016/j.brainresbull.2011.04.005

Imperatore, R., Morello, G., Luongo, L., Taschler, U., Romano, R., De Gregorio, D., et al. (2015). Genetic deletion of monoacylglycerol lipase leads to impaired cannabinoid receptor $\mathrm{CB}_{1} \mathrm{R}$ signaling and anxiety-like behavior. J. Neurochem. 135, 799-813. doi: 10.1111/jnc. 13267

Iiu, S., Li, T., Liu, H., Wang, X., Bo, S., Xie, Y., et al. (2016). Resveratrol exerts antidepressant properties in the chronic unpredictable mild stress model through the regulation of oxidative stress and mTOR pathway in the rat hippocampus and prefrontal cortex. Behav. Brain Res. 302, 191-199. doi: 10.1016/j.bbr.2016.01.037

Isokawa, M. (2009). Time-dependent induction of CREB phosphorylation in the hippocampus by the endogenous cannabinoid. Neurosci. Lett. 457, 53-57. doi: 10.1016/j.neulet.2009.04.003

Izumi, Y., and Zorumski, C. F. (2012). NMDA receptors, mGluR5, and endocannabinoids are involved in a cascade leading to hippocampal long-term depression. Neuropsychopharmacology 37, 609-617. doi: 10.1038/npp.2011.243

Jacob, W., Yassouridis, A., Marsicano, G., Monory, K., Lutz, B., and Wotjak, C. T. (2009). Endocannabinoids render exploratory behaviour largely independent of the test aversiveness: role of glutamatergic transmission. Genes Brain Behav. 8, 685-698. doi: 10.1111/j.1601-183x.2009.00512.x 
Jenniches, I., Ternes, S., Albayram, O., Otte, D. M., Bach, K., Bindila, L., et al. (2016). Anxiety, stress, and fear response in mice with reduced endocannabinoid levels. Biol. Psychiatry 79, 858-868. doi: 10.1016/j.biopsych. 2015.03.033

Jiang, W., Zhang, Y., Xiao, L., Van Cleemput, J., Ji, S. P., Bai, G., et al. (2005). Cannabinoids promote embryonic and adult hippocampus neurogenesis and produce anxiolytic- and antidepressant-like effects. J. Clin. Invest. 115, 3104-3116. doi: 10.1172/JCI25509

Jin, K., Xie, L., Kim, S. H., Parmentier-Batteur, S., Sun, Y., Mao, X. O., et al. (2004). Defective adult neurogenesis in $\mathrm{CB}_{1}$ cannabinoid receptor knockout mice. Mol. Pharmacol. 66, 204-208. doi: 10.1124/mol.66.2.204

Joca, S. R., and Guimarães, F. S. (2006). Inhibition of neuronal nitric oxide synthase in the rat hippocampus induces antidepressant-like effects. Psychopharmacology (Berl) 185, 298-305. doi: 10.1007/s00213-006-0326-2

Kang, E., Wen, Z., Song, H., Christian, K. M., and Ming, G. L. (2016). Adult neurogenesis and psychiatric disorders. Cold Spring Harb. Perspect. Biol. 8:a019026. doi: 10.1101/cshperspect.a019026

Karl, A., Schaefer, M., Malta, L. S., Dörfel, D., Rohleder, N., and Werner, A. (2006). A meta-analysis of structural brain abnormalities in PTSD. Neurosci. Biobehav. Rev. 30, 1004-1031. doi: 10.1016/j.neubiorev.2006.03.004

Katona, I., Sperlagh, B., Sik, A., Käfalvi, A., Vizi, E. S., Mackie, K., et al. (1999). Presynaptically located $\mathrm{CB}_{1}$ cannabinoid receptors regulate GABA release from axon terminals of specific hippocampal interneurons. J. Neurosci. 19, 4544-4558.

Kempermann, G. (2002). Why new neurons? Possible functions for adult hippocampal neurogenesis. J. Neurosci. 22, 635-638.

Kempermann, G., Fabel, K., Ehninger, D., Babu, H., Leal-Galicia, P., Garthe, A., et al. (2010). Why and how physical activity promotes experience-induced brain plasticity. Front. Neurosci. 4:189. doi: 10.3389/fnins.2010.00189

Kempermann, G., and Kronenberg, G. (2003). Depressed new neurons-adult hippocampal neurogenesis and a cellular plasticity hypothesis of major depression. Biol. Psychiatry 54, 499-503. doi: 10.1016/s0006-3223(03)00319-6

Kempermann, G., Song, H., and Gage, F. H. (2015). Neurogenesis in the adult hippocampus. Cold Spring Harb. Perspect. Biol. 7:a018812. doi: 10.1101/cshperspect.a018812

Kim, J. J., Foy, M. R., and Thompson, R. F. (1996). Behavioral stress modifies hippocampal plasticity through N-methyl-D-aspartate receptor activation. Proc. Natl. Acad. Sci. U S A 93, 4750-4753. doi: 10.1073/pnas.93.10.4750

Kim, J., and Li, Y. (2015). Chronic activation of $\mathrm{CB}_{2}$ cannabinoid receptors in the hippocampus increases excitatory synaptic transmission. J. Physiol. 593, 871-886. doi: 10.1113/jphysiol.2014.286633

Kitayama, N., Vaccarino, V., Kutner, M., Weiss, P., and Bremner, J. D. (2005). Magnetic resonance imaging (MRI) measurement of hippocampal volume in posttraumatic stress disorder: a meta-analysis. J. Affect. Disord. 88, 79-86. doi: 10.1016/j.jad.2005.05.014

Korem, N., and Akirav, I. (2014). Cannabinoids prevent the effects of a footshock followed by situational reminders on emotional processing. Neuropsychopharmacology 39, 2709-2722. doi: 10.1038/npp.2014.132

Kreitzer, A. C., Carter, A. G., and Regehr, W. G. (2001). Inhibition of interneuron firing extends the spread of endocannabinoid signaling in the cerebellum. Neuron 34, 787-796. doi: 10.1016/s0896-6273(02)00695-5

Kreitzer, A. C., and Regehr, W. G. (2001). Retrograde inhibition of presynaptic calcium influx by endogenous cannabinoids at excitatory synapses onto purkinje cells. Neuron 29, 717-727. doi: 10.1016/s0896-6273(01)00246-x

Laaris, N., Good, C. H., and Lupica, C. R. (2010). $\Delta$ 9-tetrahydrocannabinol is a full agonist at $\mathrm{CB}_{1}$ receptors on GABA neuron axon terminals in the hippocampus. Neuropharmacology 59, 121-127. doi: 10.1016/j.neuropharm.2010.04.013

Lauckner, J. E., Hille, B., and Mackie, K. (2005). The cannabinoid agonist WIN55,212-2 increases intracellular calcium via $\mathrm{CB}_{1}$ receptor coupling to Gq/11 G proteins. Proc. Natl. Acad. Sci. U S A 102, 19144-19149. doi: $10.1073 /$ pnas.0509588102

Lee, T. T., and Hill, M. N. (2013). Age of stress exposure modulates the immediate and sustained effects of repeated stress on corticolimbic cannabinoid $\mathrm{CB}_{1}$ receptor binding in male rats. Neuroscience 249, 106-114. doi: 10.1016/j. neuroscience.2012.11.017

Levone, B. R., Cryan, J. F., and O'Leary, O. F. (2015). Role of adult hippocampal neurogenesis in stress resilience. Neurobiol. Stress 1, 147-155. doi: 10.1016/j. ynstr.2014.11.003
Li, Y., and Kim, J. (2016). Deletion of $\mathrm{CB}_{2}$ cannabinoid receptors reduces synaptic transmission and long-term potentiation in the mouse hippocampus. Hippocampus 26, 275-281. doi: 10.1002/hipo.22558

Li, Y., and Kim, J. (2017). Distinct roles of neuronal and microglial $\mathrm{CB}_{2}$ cannabinoid receptors in the mouse hippocampus. Neuroscience 363, 11-25. doi: 10.1016/j.neuroscience.2017.08.053

Li, N., Lee, B., Liu, R. J., Banasr, M., Dwyer, J. M., and Iwata, M. (2010). mTORdependent synapse formation underlies the rapid antidepressant effects of NMDA antagonists. Science 329, 959-964. doi: 10.1126/science.1190287

Liang, Q., Luo, Z., Zeng, J., Chen, W., Foo, S.-S., Lee, S.-A., et al. (2016). Zika virus NS4A and NS4B Proteins deregulate Akt-mTOR signaling in human fetal neural stem cells to inhibit neurogenesis and induce autophagy. Cell Stem Cell 19, 663-671. doi: 10.1016/j.stem.2016.07.019

Lin, Q. S., Yang, Q., Liu, D. D., Sun, Z., Dang, H., Liang, J., et al. (2011). Hippocampal endocannabinoids play an important role in induction of long-term potentiation and regulation of contextual fear memory formation. Brain Res. Bull. 86, 139-145. doi: 10.1016/j.brainresbull.2011.07.011

Lisboa, S. F., Borges, A. A., Nejo, P., Fassini, A., Guimarães, F. S., and Resstel, L. B. (2015). Cannabinoid $\mathrm{CB}_{1}$ receptors in the dorsal hippocampus and prelimbic medial prefrontal cortex modulate anxiety-like behavior in rats: additional evidence. Prog. Neuropsychopharmacol. Biol. Psychiatry 59, 76-83. doi: 10.1016/j.pnpbp.2015.01.005

Liu, Q., Yu, J., Mao-Ying, Q.-L., Mi, W.-L., Li, B., Wang, Y.-Q., et al. (2008). Repeated clomipramine treatment reversed the inhibition of cell proliferation in adult hippocampus induced by chronic unpredictable stress. Pharmacogenomics J. 8, 375-383. doi: 10.1038/sj.tpj.6500485

Llorente, R., Llorente-Berzal, A., Petrosino, S., Marco, E. M., Guaza, C., Prada, C., et al. (2008). Gender-dependent cellular and biochemical effects of maternal deprivation on the hippocampus of neonatal rats: a possible role for the endocannabinoid system. Dev. Neurobiol. 68, 1334-1347. doi: 10.1002/dneu. 20666

Lomazzo, E., Bindila, L., Remmers, F., Lerner, R., Schwitter, C., Hoheisel, U., et al. (2015). Therapeutic potential of inhibitors of endocannabinoid degradation for the treatment of stress-related hyperalgesia in an animal model of chronic pain. Neuropsychopharmacology 40, 488-501. doi: 10.1038/npp.2014.198

Lomo, T. (1966). Frequency potentiation of excitatory synaptic activity in the dentate area of the hippocampal formation. Acta Physiol. Scand. 68:128.

Luine, V., Villegas, M., Martinez, C., and McEwen, B. S. (1994). Repeated stress causes reversible impairments of spatial memory performance. Brain Res. 639, 167-170. doi: 10.1016/0006-8993(94)91778-7

Lutz, B. (2009). Endocannabinoid signals in the control of emotion. Curr. Opin. Pharmacol. 9, 46-52. doi: 10.1016/j.coph.2008.12.001

Lutz, B., Marsicano, G., Maldonado, R., and Hillard, C. J. (2016). The endocannabinoid system in guarding against fear, anxiety and stress. Nat. Rev. Neurosci. 16, 705-718. doi: 10.1038/nrn4036

Lynch, G. S., Dunwiddie, T., and Gribkoff, V. (1977). Heterosynaptic depression: a postsynaptic correlate of long-term potentiation. Nature 266, 737-739. doi: 10.1038/266737a0

Ma, T., Hoeffer, C. A., Capetillo-Zarate, E., Yu, F., Wong, H., Lin, M. T., et al. (2010). Dysregulation of the mTOR pathway mediates impairment of synaptic plasticity in a mouse model of Alzheimer's disease. PLoS One 5:e12845. doi: 10.1371/journal.pone.0012845

Maccarrone, M., Guzmán, M., Mackie, K., Doherty, P., and Harkany, T. (2014). Programming of neural cells by (endo)cannabinoids: from physiological rules to emerging therapies. Nat. Rev. Neurosci. 15, 786-801. doi: 10.1038/ nrn3846

Mackie, K., Lai, Y., Westenbroek, R., and Mitchell, R. (1995). Cannabinoids activate an inwardly rectifying potassium conductance and inhibit Q-type calcium currents in AtT20 cells transfected with rat brain cannabinoid receptor. J. Neurosci. 15, 6552-6561.

Magariños, A. M., and McEwen, B. S. (1995). Stress-induced atrophy of apical dendrites of hippocampal CA3c neurons: involvement of glucocorticoid secretion and excitatory amino acid receptors. Neuroscience 69, 89-98. doi: 10.1016/0306-4522(95)00259-1

Magariños, A. M. A., McEwen, B. S., Flügge, G., and Fuchs, E. (1996). Chronic psychosocial stress causes apical dendritic atrophy of hippocampal CA3 pyramidal neurons in subordinate tree shrews. J. Neurosci. 16, 3534-3540. 
Mahfouz, M., Makar, A. B., Ghoneim, M. T., and Mikhail, M. M. (1975). Effect of hashish on brain $\gamma$ aminobutyric acid system, blood fibrinolytic activity and glucose and some serum enzymes in the rat. Pharmazie 30, 772-774.

Malberg, J. E. (2004). Implications of adult hippocampal neurogenesis in antidepressant action. J. Psychiatry Neurosci. 29, 196-205.

Marco, E. M., Echeverry-Alzate, V., López-Moreno, J. A., Giné, E., Peñasco, S., and Viveros, M. P. (2014). Consequences of early life stress on the expression of endocannabinoid-related genes in the rat brain. Behav. Pharmacol. 25, 547-556. doi: 10.1097/FBP.0000000000000068

Marco, E. M., Scattoni, M. L., Rapino, C., Ceci, C., Chaves, N., Macri, S., et al. (2013). Emotional, endocrine and brain anandamide response to social challenge in infant male rats. Psychoneuroendocrinology 38, 2152-2162. doi: 10.1016/j.psyneuen.2013.04.004

Marsicano, G., Wotjak, C. T., Azad, S. C., Bisogno, T., Rammes, G., Cascio, M. G., et al. (2002). The endogenous cannabinoid system controls extinction of aversive memories. Nature 418, 530-534. doi: 10.1038/nature00839

Matsuda, L. A., Lolait, S. J., Browntein, M. J., Young, A. C., and Bonner, T. I. (1990). Structure of a cannabinoid receptor and functional expression of the cloned cDNA. Nature 346, 561-564. doi: 10.1038/346561a0

Matsuzaki, M., Honkura, N., Ellis-Davies, G. C. R., and Kasai, H. (2004). Structural basis of long-term potentiation in single dendritic spines. Nature 429, 761-766. doi: 10.1038 /nature 02617

McEwen, B. S. (1999). Stress and hippocampal plasticity. Annu. Rev. Neurosci. 22, 105-122. doi: 10.1146/annurev.neuro.22.1.105

McEwen, B. S., Gray, J. D., and Nasca, C. (2015). Recognizing resilience: learning from the effects of stress on the brain. Neurobiol. Stress 1, 1-11. doi: 10.1016/j. ynstr.2014.09.001

McGaugh, J. L. (2015). Consolidating memories. Annu. Rev. Psychol. 66, 1-24. doi: 10.1146/annurev-psych-010814-014954

McLaughlin, R. J., Hill, M. N., Morrish, A. C., and Gorzalka, B. B. (2007). Local enhancement of cannabinoid $\mathrm{CB}_{1}$ receptor signalling in the dorsal hippocampus elicits an antidepressant-like effect. Behav. Pharmacol. 18, 431-438. doi: 10.1097/fbp.0b013e3282ee7b44

Mecha, M., Feliú, A., Carrillo-Salinas, F. J., Rueda-Zubiaurre, A., OrtegaGutiérrez, S., de Sola, R. G., et al. (2015). Endocannabinoids drive the acquisition of an alternative phenotype in microglia. Brain Behav. Immun. 49, 233-245. doi: 10.1016/j.bbi.2015.06.002

Mechoulam, R., Ben-Shabat, S., Hanus, L., Lingumski, N. E., Schatz, A. R., Gopher, A., et al. (1995). Identification of an endogenous 2-monoglyceride, present in canine gut, that binds to cannabinoid receptors. Biochem. Pharmacol. 50, 83-90. doi: 10.1016/0006-2952(95)00109-d

Mechoulam, R., and Parker, L. A. (2013). The endocannabinoid system and the brain. Annu. Rev. Psychol. 64, 21-47. doi: 10.1146/annurev-psych-113011143739

Mehta, M. R. (2004). Cooperative LTP can map memory sequences on dendritic branches. Trends Neurosci. 27, 69-72. doi: 10.1016/j.tins.2003.12.004

Micale, V., Stepan, J., Jurik, A., Pamplona, F. A., Marsch, R., Drago, F., et al. (2017). Extinction of avoidance behavior by safety learning depends on endocannabinoid signaling in the hippocampus. J. Psychiatr. Res. 90, 46-59. doi: 10.1016/j.jpsychires.2017.02.002

Millan, M. J. (2003). The neurobiology and control of anxious states. Prog. Neurobiol. 70, 83-244. doi: 10.1016/s0301-0082(03)00087-x

Minocci, D., Massei, J., Martino, A., Milianti, M., Piz, L., Di Bello, D., et al. (2011). Genetic association between bipolar disorder and 524A>C (Leu133Ile) polymorphism of $\mathrm{CNR} 2$ gene, encoding for $\mathrm{CB}_{2}$ cannabinoid receptor. J. Affect. Disord. 134, 427-430. doi: 10.1016/j.jad.2011.05.023

Misner, D. L., and Sullivan, J. M. (1999). Mechanism of cannabinoid effects on long-term potentiation and depression in hippocampal $\mathrm{CA}_{1}$ neurons. J. Neurosci. 19, 6795-6805.

Monfils, M.-H., VandenBerg, P. M., Kleim, J. A., and Teskey, G. C. (2004). Longterm potentiation induces expanded movement representations and dendritic hypertrophy in layer V of rat sensorimotor neocortex. Cereb. Cortex 14, 586-593. doi: 10.1093/cercor/bhh020

Monteleone, P., Bifulco, M., Maina, G., Tortorella, A., Gazzerro, P., Proto, M. C., et al. (2010). Investigation of CNR1 and FAAH endocannabinoid gene polymorphisms in bipolar disorder and major depression. Pharmacol. Res. 61, 400-404. doi: 10.1016/j.phrs.2010.01.002
Moreira, F. A., Aguiar, D. C., Campos, A. C., Lisboa, S. F., Terzian, A. L., Resstel, L. B., et al. (2009). Antiaversive effects of cannabinoids: is the periaqueductal gray involved? Neural Plast. 2009:625469. doi: $10.1155 / 2009 / 625469$

Moreira, F. A., and Crippa, J. A. (2009). The psychiatric side-effects of rimonabant. Rev. Bras. Psiquiatr. 31, 145-153. doi: 10.1590/s1516-44462009000200012

Morena, M., and Campolongo, P. (2014). The endocannabinoid system: an emotional buffer in the modulation of memory function. Neurobiol. Learn. Mem. 112, 30-43. doi: 10.1016/j.nlm.2013.12.010

Morena, M., Roozendaal, B., Trezza, V., Ratano, P., Peloso, A., Hauer, D., et al. (2014). Endogenous cannabinoid release within prefrontal-limbic pathways affects memory consolidation of emotional training. Proc. Natl. Acad. Sci. US A 111, 18333-18338. doi: 10.1073/pnas.1420285111

Morgan, N. H., Stanford, I. M., and Woodhall, G. L. (2009). Functional $\mathrm{CB}_{2}$ type cannabinoid receptors at CNS synapses. Neuropharmacology 57, 356-368. doi: 10.1016/j.neuropharm.2009.07.017

Morris, R. G. M., Anderson, E., Lynch, G. S., and Baudry, M. (1986). Selective impairment of learning and blockade of long-term potentiation by an N-methyl-D-aspartate receptor antagonist, AP5. Nature 319, 774-776. doi: $10.1038 / 319774 \mathrm{a} 0$

Munro, S., Thomas, K. L., and Abu-Shaar, M. (1993). Molecular characterization of a peripheral receptor for cannabinoids. Nature 365, 61-65. doi: 10.1038/365061a0

Muntoni, A. L., Pillolla, G., Melis, M., Perra, S., Gessa, G. L., and Pistis, M. (2006). Cannabinoids modulate spontaneous neuronal activity and evoked inhibition of locus coeruleus noradrenergic neurons. Eur. J. Neurosci. 23, 2385-2394. doi: 10.1111/j.1460-9568.2006.04759.x

Navarrete, M., and Araque, A. (2008). Endocannabinoids mediate neuronastrocyte communication. Neuron 57, 883-893. doi: 10.1016/j.neuron.2008. 01.029

Navarrete, M., and Araque, A. (2010). Endocannabinoids potentiate synaptic transmission through stimulation of astrocytes. Neuron 68, 113-126. doi: 10.1016/j.neuron.2010.08.043

Navarria, A., Tamburella, A., Iannotti, F. A., Micale, V., Camillieri, G., Gozzo, L., et al. (2014). The dual blocker of FAAH/TRPV1 N-arachidonoylserotonin reverses the behavioral despair induced by stress in rats and modulates the HPA-axis. Pharmacol. Res. 87, 151-159. doi: 10.1016/j.phrs.2014.04.014

Nowicky, A. V., Teyler, T. J., and Vardaris, R. M. (1987). The modulation of long-term potentiation by $\Delta$-9-tetrahydrocannabinol in the rat hippocampus, in vitro. Brain Res. Bull. 19, 663-672. doi: 10.1016/0361-9230(87) 90052-9

Núñez, E., Benito, C., Pazos, M. R., Barbachano, A., Fajardo, O., González, S., et al. (2004). Cannabinoid $\mathrm{CB}_{2}$ receptors are expressed by perivascular microglial cells in the human brain: an immunohistochemical study. Synapse 53, 208-213. doi: 10.1002/syn.20050

Oddi, S., Latini, L., Viscomi, M. T., Bisicchia, E., Molinari, M., and Maccarrone, M. (2012). Distinct regulation of nNOS and iNOS by $\mathrm{CB}_{2}$ receptor in remote delayed neurodegeneration. J. Mol. Med. (Berl) 90, 371-387. doi: 10.1007/s00109-011-0846-Z

Ohno-Shosaku, T., Hashimotodani, Y., Ano, M., Takeda, S., Tsubokawa, H., and Kano, M. (2007). Endocannabinoid signalling triggered by NMDA receptormediated calcium entry into rat hippocampal neurons. J. Physiol. 584, 407-418. doi: 10.1113/jphysiol.2007.137505

Pacher, P., and Kunos, G. (2013). Modulating the endocannabinoid system in human health and disease - successes and failures. FEBS J. 280, 1918-1943. doi: $10.1111 /$ febs. 12260

Palazuelos, J., Aguado, T., Egia, A., Mechoulam, R., Guzmán, M., and GalveRoperh, I. (2006). Non-psychoactive $\mathrm{CB}_{2}$ cannabinoid agonists stimulate neural progenitor proliferation. FASEB J. 20, 2405-2407. doi: 10.1096/fj.066164 fje

Palazuelos, J., Ortega, Z., Díaz-Alonso, J., Guzmán, M., and Galve-Roperh, I. (2012). $\mathrm{CB}_{2}$ cannabinoid receptors promote neural progenitor cell proliferation via mTORC1 signaling. J. Biol. Chem. 287, 1198-1209. doi: 10.1074/jbc.M111. 291294

Pamplona, F. A., Prediger, R. D., Pandolfo, P., and Takahashi, R. N. (2006). The cannabinoid receptor agonist WIN 55,212-2 facilitates the extinction of contextual fear memory and spatial memory in rats. Psychopharmacology 188, 641-649. doi: 10.1007/s00213-006-0514-0 
Park, H., Rhee, J., Lee, S., and Chung, C. (2017). Selectively impaired endocannabinoid-dependent long-term depression in the lateral habenula in an animal model of depression. Cell Rep. 20, 289-296. doi: 10.1016/j.celrep.2017. 06.049

Patel, S., Kingsley, P. J., Mackie, K., Marnett, L. J., and Winder, D. G. (2009). Repeated homotypic stress elevates 2 -arachidonoylglycerol levels and enhances short-term endocannabinoid signaling at inhibitory synapses in basolateral amygdala. Neuropsychopharmacology 34, 2699-2709. doi: 10.1038/npp. 2009.101

Patel, S., Roelke, C. T., Rademacher, D. J., Cullinan, W. E., and Hillard, C. J. (2004). Endocannabinoid signaling negatively modulates stress-induced activation of the hypothalamic-pituitary-adrenal axis. Endocrinology 145, 5431-5438. doi: 10.1210/en.2004-0638

Paton, G. S., Pertwee, R. G., and Davies, S. N. (1998). Correlation between cannabinoid mediated effects on paired pulse depression and induction of long term potentiation in the rat hippocampal slice. Neuropharmacology 37, 1123-1130. doi: 10.1016/s0028-3908(98)00096-3

Pham, K., Nacher, J., Hof, P. R., and McEwen, B. S. (2003). Repeated restraint stress suppresses neurogenesis and induces biphasic PSA-NCAM expression in the adult rat dentate gyrus. Eur. J. Neurosci. 17, 879-886. doi: 10.1046/j.14609568.2003.02513.x

Puighermanal, E., Marsicano, G., Busquets-Garcia, A., Lutz, B., Maldonado, R., and Ozaita, A. (2009). Cannabinoid modulation of hippocampal long-term memory is mediated by mTOR signaling. Nat. Neurosci. 12, 1152-1158. doi: $10.1038 / \mathrm{nn} .2369$

Rabinak, C. A., Angstadt, M., Sripada, C. S., Abelson, J. L., Liberzon, I., Milad, M. R., et al. (2013). Cannabinoid facilitation of fear extinction memory recall in humans. Neuropharmacology 64, 396-402. doi: 10.1016/j.neuropharm. 2012.06.063

Radley, J. J., and Sawchenko, P. E. (2011). A common substrate for prefrontal and hippocampal inhibition of the neuroendocrine stress response. J. Neurosci. 31, 9683-9695. doi: 10.1523/jneurosci.6040-10.2011

Reich, C. G., Mihalik, G. R., Iskander, A. N., Seckler, J. C., and Weiss, M. S. (2013). Adolescent chronic mild stress alters hippocampal $\mathrm{CB}_{1}$ receptormediated excitatory neurotransmission and plasticity. Neuroscience 253, 444-454. doi: 10.1016/j.neuroscience.2013.08.066

Reich, C. G., Taylor, M. E., and McCarthy, M. M. (2009). Differential effects of chronic unpredictable stress on hippocampal $\mathrm{CB}_{1}$ receptors in male and female rats. Behav. Brain Res. 203, 264-269. doi: 10.1016/j.bbr.2009.05.013

Revest, J. M., Dupret, D., Koehl, M., Funk-Reiter, C., Grosjean, N., Piazza, P. V., et al. (2009). Adult hippocampal neurogenesis is involved in anxiety-related behaviors. Mol. Psychiatry 14, 959-967. doi: 10.1038/mp.2009.15

Rice, J. P., Goate, A., Williams, J. T., Bierut, L., Dorr, D., Wu, W., et al. (1997). Initial genome scan of the NIMH genetics initiative bipolar pedigrees: chromosomes 1, 6, 8, 10 and 12. Am. J. Med. Genet. 74, 247-253. doi: 10.1002/ (SICI) 1096-8628(19970531)74:3<247::AID-AJMG3>3.0.CO;2-N

Riebe, C. J., and Wotjak, C. T. (2011). Endocannabinoids and stress. Stress 14, 384-397. doi: 10.3109/10253890.2011.586753

Robbe, D., Kopf, M., Remaury, A., Bockaert, J., and Manzoni, O. J. (2002). Endogenous cannabinoids mediate long-term synaptic depression in the nucleus accumbens. Proc. Natl. Acad. Sci. U S A 99, 8384-8388. doi: 10.1073/pnas. 122149199

Robertson, J. M., Achua, J. K., Smith, J. P., Prince, M. A., Staton, C. D., Ronan, P. J., et al. (2017). Anxious behavior induces elevated hippocampal $\mathrm{CB}_{2}$ receptor gene expression. Neuroscience 352, 273-284. doi: 10.1016/j.neuroscience.2017. 03.061

Romine, J., Gao, X., Xu, X.-M., So, K. F., and Chen, J. (2015). The proliferation of amplifying neural progenitor cells is impaired in the aging brain and restored by the mTOR pathway activation. Neurobiol. Aging 36, 1716-1726. doi: 10.1016/j.neurobiolaging.2015.01.003

Roohbakhsh, A., Moghaddam, A. H., Massoudi, R., and Zarrindast, M. R. (2007). Role of dorsal hippocampal cannabinoid receptors and nitric oxide in anxiety like behaviours in rats using the elevated plus-maze test. Clin. Exp. Pharmacol. Physiol. 34, 223-229. doi: 10.1111/j.1440-1681.2007.04576.x

Rossi, S., De Chiara, V., Musella, A., Kusayanagi, H., Mataluni, G., Bernardi, G., et al. (2008). Chronic psychoemotional stress impairs cannabinoid-receptormediated control of GABA transmission in the striatum. J. Neurosci. 28, 7284-7292. doi: 10.1523/JNEUROSCI.5346-07.2008
Rubino, T., Guidali, C., Vigano, D., Realini, N., Valenti, M., Massi, P., et al. (2008). $\mathrm{CB}_{1}$ receptor stimulation in specific brain areas differently modulate anxiety-related behaviour. Neuropharmacology 54, 151-160. doi: 10.1016/j. neuropharm.2007.06.024

Ruehle, S., Rey, A. A., Remmers, F., and Lutz, B. (2012). The endocannabinoid system in anxiety, fear memory and habituation. J. Psychopharmacol. 26, 23-39. doi: $10.1177 / 0269881111408958$

Saito, V. M., Wotjak, C. T., and Moreira, F. A. (2010). Pharmacological exploitation of the endocannabinoid system: new perspectives for the treatment of depression and anxiety disorders? Rev. Bras. Psiquiatr. 32, S7-S14. doi: 10.1590/S1516-44462010000500004

Santana, F., Sierra, R. O., Haubrich, J., Crestani, A. P., Duran, J. M., de Freitas Cassini, L., et al. (2016). Involvement of the infralimbic cortex and $\mathrm{CA}_{1}$ hippocampal area in reconsolidation of a contextual fear memory through $\mathrm{CB}_{1}$ receptors: effects of CP55,940. Neurobiol. Learn. Mem. 127, 42-47. doi: 10.1016/j.nlm.2015.11.016

Santarelli, L., Saxe, M., Gross, C., Surget, A., Battaglia, F., Dulawa, S., et al. (2003). Requirement of hippocampal neurogenesis for the behavioral effects of antidepressants. Science 301, 805-809. doi: 10.1126/science. 1083328

Sapolsky, R. M. (2004). Is impaired neurogenesis relevant to the affective symptoms of depression? Biol. Psychiatry 56, 137-139. doi: 10.1016/j.biopsych. 2004.04.012

Schlosburg, J. E., Blankman, J. L., Long, J. Z., Nomura, D. K., Pan, B., Kinsey, S. G., et al. (2010). Chronic monoacylglycerol lipase blockade causes functional antagonism of the endocannabinoid system. Nat. Neurosci. 13, 1113-1119. doi: $10.1038 / \mathrm{nn} .2616$

Seo, M. K., Choi, C. M., McIntyre, R. S., Cho, H. Y., Lee, C. H., Mansur, R. B., et al. (2017). Effects of escitalopram and paroxetine on mTORC1 signaling in the rat hippocampus under chronic restraint stress. BMC Neurosci. 18:39. doi: 10.1186/s12868-017-0357-0

Sheline, Y. I. (1996). Hippocampal atrophy in major depression: a result of depression-induced neurotoxicity? Mol. Psychiatry 1, 298-299.

Shoshan, N., Segev, A., Abush, H., Mizrachi Zer-Aviv, T., and Akirav, I. (2017). Cannabinoids prevent the differential long-term effects of exposure to severe stress on hippocampal- and amygdala-dependent memory and plasticity. Hippocampus 27, 1093-1109. doi: 10.1002/hipo.22755

Sinha, R., Lacadie, C. M., Constable, R. T., and Seo, D. (2016). Dynamic neural activity during stress signals resilient coping. Proc. Natl. Acad. Sci. U S A 113, 8837-8842. doi: 10.1073/pnas.1600965113

Sklenovský, A., Navrátil, J., Hrbek, J., and Krejcí, Z. (1974). Effect of $\Delta-9$ tetrahydrocannabinol on free amino acids in brain. Act. Nerv. Super. (Praha) $16,216-217$.

Smaga, I., Jastrzebska, J., Zaniewska, M., Bystrowska, B., Gawliński, D., FaronGörecka, A., et al. (2017). Changes in the brain endocannabinoid system in rat models of depression. Neurotox. Res. 31, 421-435. doi: 10.1007/s12640-0179708-y

Smith, M. A., Makino, S., Kvetnansky, R., and Port, R. M. (1995). Stress and glucocorticoids affect the expression of brain-derived neurotrophic factor and neurotrophin-3 mRNAs in the hippocampus. J. Neurosci. 15, 1768-1777.

Snyder, J. S., Soumier, A., Brewer, M., Pickel, J., and Cameron, H. A. (2011). Adult hippocampal neurogenesis buffers stress responses and depressive behaviour. Nature 476, 458-461. doi: 10.1038/nature10287

Song, Y., Zhang, J., and Chen, C. (2015). Fine-tuning of synaptic upscaling at excitatory synapses by endocannabinoid signaling is mediated via the $\mathrm{CB}_{1}$ receptor. Sci. Rep. 5:16257. doi: 10.1038/srep16257

Spiacci, G. B., Antero, L. S., Reis, D. G., Lisboa, S. F., and Resstel, L. B. (2016). Dorsal hippocampus cannabinoid type 1 receptors modulate the expression of contextual fear conditioning in rats: Involvement of local glutamatergic/nitrergic and GABAergic neurotransmissions. Eur. Neuropsychopharmacol. 26, 1579-1589. doi: 10.1016/j.euroneuro.2016. 08.010

Steiner, M. A., and Wotjak, C. T. (2008). Role of the endocannabinoid system in regulation of the hypothalamic-pituitary-adrenocortical axis. Prog. Brain Res. 170, 397-432. doi: 10.1016/S0079-6123(08)00433-0

Stella, N., Schweitzer, P., and Piomelli, D. (1997). A second endogenous cannabinoid that modulates long-term potentiation. Nature 388, 773-778. doi: $10.1038 / 42015$ 
Stempel, A. V., Stumpt, A., Zhang, H. Y., ozdogan, T., Pannash, U., Theis, A. K., et al. (2016). Cannabinoid type 2 receptors mediate a cell type-specific plasticity in the hippocampus. Neuron 90, 795-809. doi: 10.1016/j.neuron.2016. 03.034

Suárez, J., Llorente, R., Romero-Zerbo, S. Y., Mateos, B., Bermúdez-Silva, F. J., de Fonseca, F. R., et al. (2009). Early maternal deprivation induces gender-dependent changes on the expression of hippocampal $\mathrm{CB}_{1}$ and $\mathrm{CB}_{2}$ cannabinoid receptors of neonatal rats. Hippocampus 19, 623-632. doi: 10.1002/hipo.20537

Suárez, J., Rivera, P., Llorente, R., Romero-Zerbo, S. Y., Bermúdez-Silva, F. J., de Fonseca, F. R., et al. (2010). Early maternal deprivation induces changes on the expression of 2-AG biosynthesis and degradation enzymes in neonatal rat hippocampus. Brain Res. 1349, 162-173. doi: 10.1016/j.brainres.2010. 06.042

Talani, G., Licheri, V., Biggio, F., Locci, V., Mostallino, M. C., Secci, P. P., et al. (2016). Enhanced glutamatergic synaptic plasticity in the hippocampal $\mathrm{CA}_{1}$ field of food-restricted rats: involvement of $\mathrm{CB}_{1}$ receptors. Neuropsychopharmacology 41, 1308-1318. doi: 10.1038/npp. 2015.280

Tao, Y., Li, L., Jiang, B., Feng, Z., Yang, L., Tang, J., et al. (2016). Cannabinoid receptor-2 stimulation suppresses neuroinflammation by regulating microglial M1/M2 polarization through the cAMP/PKA pathway in an experimental GMH rat model. Brain Behav. Immun. 58, 118-129. doi: 10.1016/j.bbi.2016. 05.020

Terranova, J. P., Michaud, J. C., Le Fur, G., and Soubrié, P. (1995). Inhibition of long-term potentiation in rat hippocampal slices by anandamide and WIN55212-2: reversal by SR141716 A, a selective antagonist of $\mathrm{CB}_{1}$ cannabinoid receptors. Naunyn Schmiedebergs Arch. Pharmacol. 352, 576-579. doi: 10.1007/bf00169393

Toni, N., Buchs, P. A., Nikonenko, I., Bron, C. R., and Muller, D. (1999). LTP promotes formation of multiple spine synapses between a single axon terminal and a dendrite. Nature 402, 421-425. doi: 10.1038/46574

Tsou, K., Brown, S., Sañudo-Peña, M. C., Mackie, K., and Walker, J. M. (1998). Immunohistochemical distribution of cannabinoid $\mathrm{CB}_{1}$ receptors in the rat central nervous system. Neuroscience 83, 393-411. doi: 10.1016/s03064522(97)00436-3

Valverde, O., and Torrens, M. (2012). $\mathrm{CB}_{1}$ receptor-deficient mice as a model for depression. Neuroscience 204, 193-206. doi: 10.1016/j.neuroscience.2011. 09.031

Vinod, K. Y., Xie, S., Psychoyos, D., Hungund, B. L., Cooper, T. B., and TejaniButt, S. M. (2012). Dysfunction in fatty acid amide hydrolase is associated with depressive-like behavior in Wistar Kyoto rats. PLoS One 7:e36743. doi: 10.1371/journal.pone.0036743

Wamsteeker, J. I., Kuzmiski, J. B., and Bains, J. S. (2010). Repeated stress impairs endocannabinoid signaling in the paraventricular nucleus of the hypothalamus. J. Neurosci. 30, 11188-11196. doi: 10.1523/jneurosci.1046-10.2010

Wang, Y., Gu, N., Duan, T., Kesner, P., Blaskovits, F., Liu, J., et al. (2017). Monoacylglycerol lipase inhibitors produce pro- or antidepressant responses via hippocampal $\mathrm{CA}_{1}$ GABAergic synapses. Mol. Psychiatry 22, 215-226. doi: $10.1038 / \mathrm{mp} .2016 .22$

Wang, M., Hill, M. N., Zhang, L., Gorzalka, B. B., Hillard, C. J., and Alger, B. E. (2012). Acute restraint stress enhances hippocampal endocannabinoid function via glucocorticoid receptor activation. J. Psychopharmacol. 26, 56-70. doi: 10.1177/0269881111409606

Wang, W., Jia, Y., Pham, D. T., Palmer, L. C., Jung, K. M., Cox, C. D., et al. (2017). Atypical endocannabinoid signaling initiates a new form of memory-related plasticity at a cortical input to hippocampus. Cereb. Cortex doi: 10.1093/cercor/bhx126 [Epub ahead of print].

Wang, Y., and Zhang, X. (2017). FAAH inhibition produces antidepressant-like efforts of mice to acute stress via synaptic long-term depression. Behav. Brain Res. 324, 138-145. doi: 10.1016/j.bbr.2017.01.054

Watanabe, Y., Gould, E., and McEwen, B. S. (1992). Stress induces atrophy of apical dendrites of hippocampal CA3 pyramidal neurons. Brain Res. 588, 341-345. doi: 10.1016/0006-8993(92)91597-8

Willner, P., Muscat, R., and Papp, M. (1992). Chronic mild stress-induced anhedonia: a realistic animal model of depression. Neurosci. Biobehav. Rev. 16, 525-534. doi: 10.1016/s0149-7634(05)80194-0
Wilson, R. I., Kunos, G., and Nicoll, R. A. (2001). Presynaptic specificity of endocannabinoid signaling in the hippocampus. Neuron 31, 453-462. doi: 10.1016/s0896-6273(01)00372-5

Wilson, R. I., and Nicoll, R. A. (2001). Endogenous cannabinoids mediate retrograde signalling at hippocampal synapses. Nature 410, 588-592. doi: 10.1038/35069076

Wise, L. E., Thorpe, A. J., and Lichtman, A. H. (2009). Hippocampal $\mathrm{CB}_{1}$ receptors mediate the memory impairing effects of $\Delta^{9}$-tetrahydrocannabinol. Neuropsychopharmacology 34, 2072-2080. doi: 10.1038/npp.2009.31

Wolf, S. A., Bick-Sander, A., Fabel, K., Leal-Galicia, P., Tauber, S., RamirezRodriguez, G., et al. (2010). Cannabinoid receptor $\mathrm{CB}_{1}$ mediates baseline and activity-induced survival of new neurons in adult hippocampal neurogenesis. Cell Commun. Signal. 8:12. doi: 10.1186/1478-811x-8-12

Woolley, C. S., Gould, E., and McEwen, B. S. (1990). Exposure to excess glucocorticoids alters dendritic morphology of adult hippocampal pyramidal neurons. Brain Res. 531, 225-231. doi: 10.1016/0006-8993(90)90778-a

Xia, B., Chen, C., Zhang, H., Xue, W., Tang, J., Tao, W., et al. (2016). Chronic stress prior to pregnancy potentiated long-lasting postpartum depressive-like behavior, regulated by Akt-mTOR signaling in the hippocampus. Sci. Rep. 6:35042. doi: 10.1038/srep35042

Xu, J., Dong, H., Qian, Q., Zhang, X., Wang, Y., Jin, W., et al. (2017). Astrocytederived CCL2 participates in surgery-induced cognitive dysfunction and neuroinflammation via evoking microglia activation. Behav. Brain Res. 332, 145-153. doi: 10.1016/j.bbr.2017.05.066

Yun, S., Reynolds, R. P., Masiulis, I., and Eisch, A. J. (2016). Re-evaluating the link between neuropsychiatric disorders and dysregulated adult neurogenesis. Nat. Med. 22, 1239-1247. doi: 10.1038/nm.4218

Zarrindast, M. R., Nasehi, M., Piri, M., and Bina, P. (2010). Anxiety-like behavior induced by histaminergic agents can be prevented by cannabinoidergic WIN55,212-2 injected into the dorsal hippocampus in mice. Pharmacol. Biochem. Behav. 94, 387-396. doi: 10.1016/j.pbb.2009.09.021

Zhang, Z., Wang, W., Zhong, P., Liu, S. J., Long, J. Z., Zhao, L., et al. (2015). Blockade of 2-arachidonoylglycerol hydrolysis produces antidepressant-like effects and enhances adult hippocampal neurogenesis and synaptic plasticity. Hippocampus 25, 16-26. doi: 10.1002/hipo.22344

Zhong, P., Wang, W., Pan, B., Liu, X., Zhang, Z., Long, J. Z., et al. (2014). Monoacylglycerol lipase inhibition blocks chronic stressinduced depressive-like behaviors via activation of mTOR signaling. Neuropsychopharmacology 39, 1763-1776. doi: 10.1038/npp.2014.24

Zhu, P. J., and Lovinger, D. M. (2007). Persistent synaptic activity produces long-lasting enhancement of endocannabinoid modulation and alters long-term synaptic plasticity. J. Neurophysiol. 97, 4386-4389. doi: 10.1152/jn. 01228.2006

Zhuang, F., Li, M., Gao, X., Wang, Y., Wang, D., Ma, X., et al. (2016). The antidepressant-like effect of alarin is related to TrkB-mTOR signaling and synaptic plasticity. Behav. Brain Res. 313, 158-171. doi: 10.1016/j.bbr.2016. 06.057

Conflict of Interest Statement: Author NCF-J has a fellowship with the Fundação de Apoio ao Ensino, Pesquisa e Assistência do Hospial das Clínicas da Faculdade de Medicina de Ribeirão Preto e Prati-Donaduzi (Toledo-Brazil). Author FSG is a co-inventor (Mechoulam R, JC, Guimãraes FS, AZ, JH, Breuer A) of the patent "Fluorinated CBD compounds, compositions and uses thereof. Pub. No.: WO/2014/108899. International Application No.: PCT/IL2014/050023” Def. US no. Reg. 62193296; 29/07/2015; INPI on 19/08/2015 (BR1120150164927).

The other authors declare that the research was conducted in the absence of any commercial or financial relationships that could be construed as a potential conflict of interest.

Copyright (c) 2017 Scarante, Vila-Verde, Detoni, Ferreira-Junior, Guimarães and Campos. This is an open-access article distributed under the terms of the Creative Commons Attribution License (CC BY). The use, distribution or reproduction in other forums is permitted, provided the original author(s) or licensor are credited and that the original publication in this journal is cited, in accordance with accepted academic practice. No use, distribution or reproduction is permitted which does not comply with these terms. 